\title{
THE RISE AND FALL OF PROMISSORY ESTOPPEL OR IS PROMISSORY ESTOPPEL REALLY AS UNSUCCESSFUL AS SCHOLARS SAY IT IS: A NEW LOOK AT THE DATA
}

\begin{abstract}
Juliet P. Kostritsky*
This Article makes important contributions to the field of empirical promissory estoppel scholarship. First it challenges recent empirical scholarship (by Professors Robert Hillman and Sidney De Long in the 1998 and 1997 Columbia and Wisconsin law reviews). Their scholarship had challenged the view of the vast majority of American Contracts scholarship by proclaiming promissory estoppel to be an unimportant doctrine based on low win rates of tried cases. My article challenges this new orthodoxy based on a comprehensive five-year survey of cases. It concludes that it is too soon to announce the death of promissory estoppel and that promissory estoppel is still a vital theory in contract. It argues that if qualitative factors relating to the weakness of a claim are accounted for in the data the win rates are significant. Second, it argues that if such qualitative factors are recognized, promissory estoppel results can be rationalized in efficiency terms. Plaintiffs tend to win claims when a positive result would enhance an efficient outcome and to lose cases in which enforcement would have negative welfare effects. Finally, the Article offers some insights into conducting empirical scholarship. It argues that it may not be possible to draw meaningful conclusions from generalized win/loss ratios without making qualitative judgments about the viability of the underlying claim.
\end{abstract}

* (C) John Homer Kapp Professor of Law, Case Western Reserve University School of Law. J.D. University of Wisconsin 1980; A.B. Harvard University 1976. I would like to thank Dean Gerald Korngold for his research support and Professors Peter A. Alces, Anthony D'Amato, Daniel A. Farber, Michael Heise, Robert A. Hillman, Sharona Hoffman, Andrew P. Morriss, and Ann Southworth for the clarity of their insights on earlier drafts. Errors are mine alone. Special thanks are owed to Professor Robert W. Gordon for inspiring me to become a teacher of and writer in Contracts. Deft research assistance and statistical analysis was provided by Brian Bolinger (J.D. C.W.R.U. expected 2002), Kara Ryf (J.D. C.W.R.U. 2001), Stephan Schlegelmilch (J.D. C.W.R.U. 2000), and Jordan Strauss (J.D. C.W.R.U. expected 2003). 


\section{BIRTH AND DEATH OF TwO DOCTRINES: CONSIDERATION AND PROMISSORY ESTOPPEL}

With the 1974 publication of The Death of Contract, Grant Gilmore created an exhilarating story chronicling the birth and death of nineteenth century bargain theory and contract. ${ }^{1}$ In Gilmore's version of history, ${ }^{2}$ Oliver Wendell Holmes, ${ }^{3}$ Samuel Williston, and Christopher Langdell devised the principal contours of classical contract law. Langdell carved out a law of contract where none had existed before, at least not as a cohesive theory. ${ }^{4}$ Williston's "meticulous" follow-up work fleshed out the details of contract theory. In this account, Justice Holmes loomed as a revolutionary "philosophical villain"6 who miraculously convinced his readers of the veracity of a false account of bargain theory. Holmes portrayed the requirement of a quid pro quo as a long-established tradition ${ }^{7}$ despite only scant support in the common law for that theory. 8 According to

1. Grant Gilmore, The Death of Contract (1974).

2. According to Richard Speidel, Gilmore's version of history is problematic. "Professor Gilmore, a self-confessed historian, has attempted a tour de force" by ignoring "280 Years of American Legal History." Richard E. Speidel, An Essay on the Reported Death and Continued Vitality of Contract, 27 STAN. L. REV. 1161, 1167-68 (1975) (book review) [hereinafter Speidel, Reported Death]. Robert Gordon identifies another weakness in Gilmore's legal historyGilmore's decision "to focus on the least distinctive aspect of 20th century contract law: the decay in integrity of a doctrinal system." Robert W. Gordon, Book Review, 1974 Wis. L. REV. 1216, 1236 (1974) (reviewing GRANT GILMORE, DEATH of ContRaCt (1974)). As Professor Gordon explains, "[t]he tone is elegiac-he seems to be saying: "Many ingenious lovely things are gone." Id. at 1239.

3. Oliver Wendell Holmes contributed to the law of contracts through his lectures on contracts. See Oliver Wendell Holmes, Lectures on Contracts, in The Common Law (Little, Brown \& Co. 1923) (1881).

4. "Langdell, then, did little more than launch the idea that there was-or should be-such a thing as a general theory of contract." GILMORE, supra note 1, at 13-14. See C.C. LANGDELl, A Selection of CASEs on the LAW of CONTRACTS (1st ed. 1871).

5. GILMORE, supra note 1 , at 14.

6. Speidel, supra note 2 , at 1161 . The enforcement of promises restricted to those supported by consideration was revolutionary itself since the requirement had not been required by the common law. GILMORE, supra note 1, at 20.

7. Holmes, supra note 3 , at 253-70, 274-88. Although bargain theory seems to represent the essence of modern contract, in fact, at the time it was proposed, "Holmes was, quite consciously, proposing revolutionary doctrine. ..." GILMORE, supra note 1, at 20.

8. Gilmore, supra note 1 , at 20-21. See PAtrick AtiYah, The Rise AND FALL OF FREEDOM OF CONTRACT 184-89 (1979) (discussing the prevalence of a concept of liability predicated on reliance rather than promise from the sixteenth century until the nineteenth century, when bargain theory became prevalent); see also Jay M. Feinman, Promissory Estoppel and Judicial Method, 97 HARV. L. REV. 678, 679 (1984) [hereinafter Feinman, Judicial Method] (discussing reliance-based theories of liability which preceded nineteenth century bargain theory). As Hillman explains, Gilmore's view was that "bargain theory was an artificial and narrow construct improvised by Langdell in his famous casebook, nurtured by Holmes in The Common Law, and restated by Williston, 
Gilmore, under these architects and visionaries, Contracts became a simple,${ }^{9}$ predictable, ${ }^{10}$ and closed system. ${ }^{11}$

Having exposed the "false theory" of consideration 12 as nothing more than a "static, abstract, manufactured, dogmatic, quaint, destructive, monstrous, and unreal" "construct," 13 destined for failure, Gilmore proceeded to re-examine the basis for promissory liability. He found that there was a "radically new way of analyzing the problem of civil obligation," 14 which shared many characteristics with the law of Torts.

In this stylized version of the rise and fall of bargain theory, Arthur Corbin ${ }^{15}$ played a pivotal role in revolutionizing the law of Contracts $^{16}$ and hastening the demise of bargain theory. Professor Corbin broke the "stranglehold" 17 of bargain theory as the exclusive arbiter of contract liability ${ }^{18}$ by presenting irrefutable case law re-

to reflect late nineteenth and early twentieth-century society's flirtation with free market economics and individualism." ROBERT A. HILlMAn, THE Richness OF CONTRACT LAW 19 (1997).

9. As Professors Goetz and Scott explain, "bargain theory' is classically simple: bargained-for promises are presumptively enforceable; nonreciprocal promises are presumptively unenforceable." Charles J. Goetz \& Robert E. Scott, Enforcing Promises: An Examination of the Basis of Contract, 89 YALE L.J. 1261, 1261-62 (1980). The classical system was also simple in its rule orientation. Judges could apply the abstract principles without the need for complicated particularized factual inquiries. Gordon identifies this abstract quality of the classical system noting "its utility ... towards construction of doctrinal cathedrals insulated against the penetration of social fact." Gordon, supra note 2, at 1233. Cf. Richard E. Speidel, Restatement Second: Omitted Terms and Contract Method, 67 CoRNELl L. REV. 785 (1982) (documenting the more flexible approach embodied in the standards-based methodology of the Restatement which eschews abstract rules and calls for a particularized factual inquiry).

10. One had to abide by the rules of contract but if one did, one could in theory predict the application of the rules with certainty. "In planning their affairs private parties could guess more accurately at the results of litigation if standards for their conduct were no longer left to juries but were synthesized into rules announced in case law . ..." Gordon, supra note 2, at 1233.

11. The classical rules, including consideration, made it difficult to enter the world of contract. "With the Holmesian formulation, consideration became a tool for narrowing the range of contractual liability." GILMORE, supra note 1, at 21 .

12. Speidel, supra note 2 , at 1161.

13. Id. at 1164 .

14. GILMORE, supra note 1 , at 101.

15. Arthur Corbin was then a professor of law at the Yale Law School and Williston's assistant in the drafting of the first Restatement of Contracts. GILMORE, supra note 1, at 59.

16. Despite Corbin's revolutionary effect on the Restatement's drafting, "he was an evolutionist." Joseph M. Perillo, Twelve Letters from Arthur L. Corbin to Robert Braucher Annotated, 50 WASH. \& LEE L. REV. 755, 757 (1993).

17. Speidel, supra note 2 , at 1161 .

18. But see Sidney W. DeLong, The New Requirement of Enforcement Reliance in Commercial Promissory Estoppel: Section 90 as Catch-22, 1997 WIS. L. REV. 943, 962 (1997) (questioning status of the role of Corbin as "an originary myth"); see also Perillo, supra note 16, at 769 n.40 (suggesting contrary account 
sults that contravened bargain theory. ${ }^{19}$ Corbin's arguments challenged Samuel Williston, Contract's preeminent scholar ${ }^{20}$ and reporter for the first Restatement of Contracts, ${ }^{21}$ to rethink the basis of contract liability.

Corbin's arguments prevailed; the American Law Institute adopted Section 90 in 1932.22 Section 90 recognized that nonbargained for reliance could create contract liability. In so doing it created an internal contradiction within Contracts. ${ }^{23}$

of who played principal role in advocacy for reliance-based liability and noting Williston's possible authorship for Section 90).

19. Courts had found liability without bargain if a promise had induced detrimental reliance. To account for the results in those cases Corbin argued that the Restatement should recognize a liability principle to cover such results. Professor Anthony D'Amato observes this process arguing that

Williston attempted to supply a rigorous theory that would both describe and delimit "contracts." Corbin argued that Williston's theories didn't fit the empirical data, but Williston could have responded that no theory fits all the data. I'm on Williston's side here, because I think Corbin's data-collection is largely arbitrary without the Willistonian model in the background.

E-mail from Anthony D'Amato, Professor of Law, Northwestern University School of Law, to Juliet P. Kostritsky, Professor of Law, Case Western Reserve University School of Law (July 21, 2001) (on file with author).

20. Williston's massive treatise established his scholarly reputation. The Law of Contracts was first published in 1920.

21. The project of formulating restatements of the common law was undertaken by the American Law Institute (ALI) following its founding in 1923. Along with the law of Contracts, the ALI undertook to formulate restatements for the law of Agency, Conflict of Laws, Judgments, Property, Restitution, Security, Torts, and Trusts. Gilmore thought that the project of formulating a Restatement of Contracts was an effort to stave off the more revolutionary forces for change. Indeed, Gilmore saw the formulation of undertaking the Restatements "as 'the almost instinctive reaction of the legal establishment of the time to the attack of the so-called legal realists' and as a final desperate attempt to preserve 'unity of doctrine' in an 'essentially pure case law system."' GILMORE, supra note 1, at 67 (citing Grant Gilmore, Legal Realism: Its Cause and Cure, 70 YALE L.J. 1037 (1961)).

22. "A promise which the promisor should reasonably expect to induce action or forbearance of a definite and substantial character on the part of the promisee and which does induce such action or forbearance is binding if injustice can be avoided only by enforcement of the promise." RESTATEMENT OF CONTRACTS $\S 90$ (1932). This section was slightly modified in the 1979 adoption of the Restatement (Second) of Contracts. Currently Section 90 provides:

Promise Reasonably Inducing Action or Forbearance

(1) A promise which the promisor should reasonably expect to induce action or forbearance on the part of the promisee or a third person and which does induce such action or forbearance is binding if injustice can be avoided only by enforcement of the promise. The remedy granted for breach may be limited as justice requires.

(2) A charitable subscription or a marriage settlement is binding under Subsection (1) without proof that the promise induced action or forbearance.

23. See Feinman, Judicial Method, supra note 8, at 685 (noting that "[t]he 
Gilmore was not content to let promissory estoppel and bargain theory coexist, however uneasily, as the Restatement drafters had done. Instead, he sounded the death knell of bargain by announcing that promissory estoppel's reliance theory "has, in effect, swallowed up the bargain principle ...."24 This prediction signaled the end of the mythical world of the dominant role of bargain in classical contract law. ${ }^{25}$

Given Gilmore's view that the case law support for Holmes's theory had been non-existent, and that "almost from the moment of its birth" 26 the Holmsian construct began to disintegrate, the triumph of reliance seemed inevitable. Gilmore resolved the contradiction between reliance theory and bargain ${ }^{27}$ by pronouncing the death of bargain theory. In this brave new world of contract, reliance, and other tort-like theories of liability had already displaced the previously predominant bargain theory, obliterating the distinction between tort and contract. 28

position of reliance in contract law-the relationship between reliance and bargain-has always been uneasy"). For a probing exploration of the friction between reliance and bargain and an account of the continued dominance of consideration principles in the application of Section 90, see Stanley D. Henderson, Promissory Estoppel and Traditional Contract Doctrine, 78 YALE L.J. 343 (1969).

24. GILMORE, supra note 1 , at 72 .

25. In some ways, Gilmore's account of the demise of the bargain theory doctrine misses one of the most fundamental developments in the study of contract law: the rise of the Behavioral Realists like Stewart Macaulay and Lawrence Friedman. Gordon, supra note 2, at 1219. Unlike the legal realists who seized on techniques for critiquing the architects of classical theory with a view towards revealing results "plainly at odds with the theory," id. at 1221, and to better educate judges, $i d$. at 1223, the Behavioral Realists undermined the importance of judges and appellate opinions as a focus of study. They probed "not only what social functions are performed by courts but also who else in society, official agencies or private parties, performs those same functions." Id. at 1223 .

26. GILMORE, supra note 1 , at 57.

27. This contradiction between bargain and reliance led Gilmore to characterize the first Restatement of Contracts as evidence of the document's "schizophrenia." Id. at 60.

28. Id. at 88. Recently, some academic commentators have begun to question Gilmore's notion that the rise of reliance theory marked the advent of tort liability and the end of contract as assent-based. Such commentators have stressed that the rise of reliance theory is in fact consistent with the tradition of contract as assent based. Both reliance and bargain theory "share unifying elemental criteria that situate them all squarely within an assent-based theory of enforceability." Juliet P. Kostritsky, A New Theory of Assent-Based Liability Emerging Under the Guise of Promissory Estoppel: An Explanation and Defense, 33 WAYNE L. REV. 895, 902 (1987) [hereinafter Kostritsky, New Theory]; see also Daniel A. Farber \& John H. Matheson, Beyond Promissory Estoppel: Contract Law and the "Invisible Handshake," 52 U. CHI. L. REV. 903, 905 (1985). Other scholars argue that the classification of promissory estoppel as tort or contract is unimportant and perhaps a distraction. "To take either approach distorts what you see under the microscope. Let the compilers of casebooks argue whether promissory estoppel should be in the contracts casebook or the torts 
After the publication of Gilmore's book,

it was widely expected that promissory estoppel would revolutionize commercial contract law by erasing the familiar demarcations between enforceable and unenforceable promises that had been drawn by the bargain theory of consideration and by introducing the uncertainty of a new form of reliancebased, tort liability into contract negotiations and relationships. ${ }^{29}$

Not every contracts scholar has accepted Gilmore's view that reliance would displace bargain theory, or that Section 90 was a tort theory. ${ }^{30}$ Nevertheless, Gilmore's thesis on the central role of reliance in contract law became a standard orthodoxy embraced by many scholars. ${ }^{31}$

casebook. Nothing much will turn on the outcome." E-mail from Anthony D'Amato, Professor of Law, Northwestern University School of Law, to Juliet P. Kostritsky, Professor of Law, Case Western Reserve University School of Law (July 21, 2001) (on file with author).

29. DeLong, supra note 18, at 944.

30. Some scholars rejected the tort-like characterization of Section 90 and promissory estoppel and argued instead that these doctrines continue to be centered around assent-based principles of contract and are merely alternative means of demonstrating "the assent required for an enforceable consensual exchange." Kostritsky, New Theory, supra note 28, at 901-02.

31. Charles Knapp called promissory estoppel "the most radical and expansive development of this century in the law of promissory liability." Charles L. Knapp, Reliance in the Revised Restatement: The Proliferation of Promissory Estoppel, 81 Colum. L. REv. 52, 53 (1981). Many commentators have agreed, assuming the increased importance of reliance and seeking to offer different rationales for that expansion. See, e.g., Farber \& Matheson, supra note 28; Henderson, supra note 23; see also Jay M. Feinman, The Significance of Contract Theory, 58 U. CIN. L. REV. 1283 (1990).

Other commentators, while accepting the dominance of promissory estoppel, debated other aspects of the doctrine, including "whether reliance or promise constituted the theory's conceptual core." Robert A. Hillman, Questioning the "New Consensus" on Promissory Estoppel: An Empirical and Theoretical Study, 98 Colum. L. Rev. 580, 586 (1998). Charles Fried and other promise theorists have continued to insist on the importance of the promise principle as the core of contract law liability, in part to promote "the liberty or moral value of enforcing promises." Id. at 586 n.38; see, e.g., Charles Fried, CONTRACT As Promise: A Theory of Contractual Obligation (1981). Other commentators stressed "the fairness of redressing detrimental reliance on a promise...." Hillman, supra, at 586 n.38.

The consensus underlying Gilmore's view on the centrality of reliance and promissory estoppel can be explained by the fact that scholars of all persuasions found something to applaud in promissory estoppel. See Farber \& Matheson, supra note 28, at 906 (discussing promissory estoppel liability in terms of its ability to "further[ ] the often divergent values proclaimed by the law and economics writers and the critical legal scholars"). Writers on the left embraced reliance as a revolutionary doctrine able to protect those harmed by broken promises that fell short of a bargain. See, e.g., Jay M. Feinman, Critical Approaches to Contract Law, 30 UCLA L. REV. 829, 860 (1983). Law and economics writers found that promissory estoppel, when considered in conjunction with 
A second, more limited strand of promissory estoppel "orthodoxy," adopted by a smaller coterie of scholars, subscribed to the view that reliance was dead as an element of promissory estoppel claims. ${ }^{32}$ These so-called "promise theorists" accepted Gilmore's orthodoxy on the centrality of promissory estoppel but went further, arguing that promissory estoppel claimants could prevail merely upon a showing of the seriousness of a promise. 33

In 1997, two scholars, Sidney DeLong and Bob Hillman, used empirical data to challenge both promissory estoppel orthodoxies and attempted a counter-revolution in American contracts scholarship. First, they disputed the centrality of promissory estoppel and proclaimed it to be an unimportant doctrine in contracts based on its overwhelming rejection by the vast majority of courts considering promissory estoppel claims. ${ }^{34}$ DeLong called promissory estoppel "a revolution that wasn't." 35 Hillman's view, based on an analysis of case outcomes, was that promissory estoppel had become a peripheral doctrine operating at the margin of contracts. Contrary to Gilmore's predictions and to the scholarly writings, promissory estoppel has turned out to be a dead letter, its revolutionary potential unfulfilled.

Second, Hillman and DeLong challenged the orthodoxy of the promise theorists. They argued that reliance is still critical to prom-

the more conservative bargain rules, offered the efficient tendencies of common law rules. They used economic models to argue that the common law's delineation between reliance and bargain promoted optimal enforcement and efficient reliance. See Goetz \& Scott, supra note 9, at 1265.

32. The following articles illustrate this scholarly viewpoint: Randy E. Barnett, The Death of Reliance, 46 J. LEGAL Educ. 518 (1996); Farber \& Matheson, supra note 28; James Gordley, Enforcing Promises, 83 CAL. L. REV. 547 (1995); Edward Yorio \& Steve Thel, The Promissory Basis of Section 90, 101 YALE L.J. 111 (1991).

33. Yorio \& Thel, supra note 32, at 112 (arguing that prior "commentators are wrong about the way courts have decided Section 90 cases. Rather than using Section 90 to compensate promisees for losses suffered in reliance, judges use it to hold people to their promises ..."); cf. Charles L. Knapp, Rescuing Reliance: The Perils of Promissory Estoppel, 49 HASTINGS L.J. 1191, 1331-32 (1998) (citing the "disservice" of the promise theorists' "marginaliz[ing] the factor of reliance").

In some ways, of course, the two "orthodoxies" are inconsistent. Gilmore's orthodoxy centered on the rise of promissory estoppel as a reliance-based, tortlike theory of liability. Promise theorists agreed on the centrality of promissory estoppel to contract but disagreed on the essential foundation for a promissory estoppel claim, arguing that the cause of action was based on promises without the need to show actual reliance.

34. Hillman, supra note 31 , at 580, 588; see also DeLong, supra note 18, at 949-50 (noting the "virtual[ ] extinguish[ment]" of promissory estoppel "by the reactive adaptation of the bar and the bench"); Phuong N. Pham, Note, The Waning of Promissory Estoppel, 79 CoRNELL L. REV. 1263, 1263 (1994) (noting "that courts, rather than enthusiastically embracing promissory estoppel theory, in fact severely limit its application").

35. DeLong, supra note 18, at 943. 
issory estoppel claimants winning, ${ }^{36}$ and is an important element in the success or failure of promissory estoppel claims. ${ }^{37}$ Hillman and DeLong's work debunked as mythical the view that it is no longer necessary for a promissory estoppel claimant to show reliance on a promise to prevail. In challenging a particular viewpoint ${ }^{38}$ held by a small but influential group of scholars-Yorio, Thel, Fried, Farber and Matheson, and Barnett39 — who had announced the death of reliance in promissory estoppel claims, ${ }^{40}$ Hillman and DeLong performed an important and necessary scholarly correction.

Yet, the effort by Hillman and DeLong to (once again) rewrite the history of promissory estoppe ${ }^{41}$ and its place in Contracts, using empirical data, is premature. Despite performing a much needed survey, empirical scholars have drawn misplaced conclusions from the data. The Hillman and DeLong data show: (1) the importance of reliance in establishing a winning claim ${ }^{42}$ and (2) on the basis of certain narrow assumptions, only marginal success rates for promissory estoppel claims. ${ }^{43}$ However, in attempting to foment a counterrevolution in promissory estoppel scholarship by announcing the demise of promissory estoppel, ${ }^{44}$ scholars have jumped hastily from

36. Id. at 981 .

37. Hillman, supra note 31 , at 597. The scholarly "consensus" on the unimportance of proving reliance was misplaced, neither supported by the case law nor matched by reality.

This finding on the continued importance of reliance is not controversial for law and economics scholars. These scholars have assumed that reliance is a central concern of promissory estoppel as part of an overall effort to foster efficient reliance, optimal enforcement of promises, and overall welfare maximization. The "reliance is dead" theory therefore never gained currency among the scholars concerned with an economic analysis of promissory estoppel. These include: Richard Craswell, Offer, Acceptance, and Efficient Reliance, 48 STAN. L. REV. 481 (1996); Goetz \& Scott, supra note 9; Avery Katz, When Should an Offer Stick? The Economics of Promissory Estoppel in Preliminary Negotiations, 105 YALE L.J. 1249, 1250 (1996) ("From a regulatory vantage point, estoppel and related legal doctrines operate as economic regulations; they shape the bargaining process by influencing the negotiators' incentives to make and to rely on preliminary communications."); Juliet P. Kostritsky, Bargaining With Uncertainty, Moral Hazard, and Sunk Costs: A Default Rule for Precontractual Negotiations, 44 Hastings L.J. 621 (1993) [hereinafter Kostritsky, Bargaining].

38. See supra note 32 (canvassing scholarship of the death of reliance proponents).

39. DeLong, supra note 18, at 981; Hillman, supra note 31, at 597.

40. See, e.g., Barnett, supra note 32 .

41. For a probing analysis of the history of promissory estoppel that explains the current uncertainties in doctrinal application in terms of a continuing "doctrinal and methodological problems of postclassical contract law," see Feinman, Judicial Method, supra note 8, at 689-90.

42. See supra notes 36-40.

43. DeLong relies on his data to argue "that Section 90 should be used to enforce only those reliance-inducing promises that are accompanied by an expression by the promisor that he intends that the promise be legally enforceable." DeLong, supra note 18, at 958 .

44. Id. at 949-50. 
overall win/loss rates to robust conclusions about the viability of promissory estoppel as a cause of action and its place in Contracts. Although Grant Gilmore may well have exaggerated when he claimed that promissory estoppel had already decimated bargain theory, the claim that "promissory estoppel may no longer be, if it ever was, a significant theory of recovery" is overstated. ${ }^{45}$

This Article argues that promissory estoppel is still a vital theory in contract. The empiricists' premature announcement of its demise derives from a failure to weave the two different components of their empirical observations-the apparent low win rates for promissory estoppel and the centrality of reliance-into one explanation. The tendency to look separately at those two factors underscores a larger weakness of the empirical scholarship: the failure to control for various characteristics of promissory estoppel opinions. Had scholars systematically explored the reliance factor (and other like factors) and the effects on outcomes in the case law, it would have been apparent that promissory estoppel is far from dead. If the reliance factor, along with other factors correlating with the weakness of a promissory estoppel claim, is accounted for in the win/loss rates, then the true contours of promissory estoppel can be seen. Promissory estoppel claimants are losing in cases in which the plaintiff's claim evidences significant weakness, and conversely, are winning at significant rates ${ }^{46}$ amongst cases that are not demonstrably weak. ${ }^{47}$ Thus, Hillman's attempted counter-revolution fails because his analysis is based on win ratios that do not control for various characteristics. Once these characteristics are controlled

45. Hillman, supra note 31, at 619. Of course, Hillman's conclusion was based solely on measuring the "win rates in the courts," id. at 619 , which were very low. One possible explanation offered by Professor Hillman for these low win rates "is that claimants are bringing weak promissory estoppel claims and not making an effort to settle them." Id. at 596. This explanation is in accord with the data and conclusions reached in this Article. However, Hillman also points to the low win rates as possible "evidence of judicial resistance to the theory" and for "a judicial souring on the theory, which is consistent with courts' recent reluctance to intervene in the contracting process on other grounds." Id. Professor Hillman's offering of different explanations for the low win rates in promissory estoppel cases highlights the difficulties inherent in interpreting win/loss rates. See infra text accompanying notes 81-101. In order to determine the significance of win/loss rates, or to draw meaningful conclusions about the win/loss rates, one must have a specific hypothesis to prove or disprove with the win/loss data. See Coffey, infra note 60. This Article will seek to resolve differences in the explanations for the low win/loss rates by looking at the particular types of factors present in cases that lose and win.

46. See Tables infra.

47. Although "weak" is an imprecise term, in this Article I have used "weak" to refer to a variety of specific procedural flaws in a promissory estoppel claimant's case, to other factors that clearly indicate that a doctrinal element of Section 90 is missing from the case, or to situations where the promissory estoppel claimant is guilty of bad conduct. See infra text accompanying notes 82 96. 
for, promissory estoppel win rates are substantial. 48

48. They are not, however, equivalent to the win rates for all contracts cases tried in federal district court. From 1978-1985, the percentage of wins for contracts cases ranged from $52 \%$ to $84 \%$. Theodore Eisenberg, Testing the Selection Effect: A New Theoretical Framework with Empirical Tests, 19 J. LEGAL STUD. 337, 357 (1990). These data are based on the Administrative Office of the United States Courts. The data comprise approximately 4.2 million federal district court cases that have terminated over the last 19 years. The Federal Judicial Center collects the data and the Inter-University Consortium for Political and Social Research publicizes the data. This data is now readily available through a Cornell University web site: http://teddy.law.cornell.edu:8090/ questcv2.htm. From 1990-1994, the contract win rate for all categories of contracts cases for all districts at the federal level ranged from $39.83 \%$ to $44.25 \%$. Id.

The federal data are problematic for several reasons. First, some of the categories of contract in the federal study, such as Recovery of Defaulted Student Loans and Recovery of Overpayments and Enforcing Judgments as well as recovery of Medicare Overpayments and Negotiable Instruments and even Miller Act cases seem unrepresentative of ordinary contracts cases since they embody causes of action in which the plaintiff success rate is likely to be very high. In at least some of these categories of cases, such as the student loan default category, one would expect close to a $100 \%$ win rate for the plaintiff who might be a bank or the U.S. Government. There are virtually no defenses that would excuse liability and so including such cases in the overall win rate would skew the results. See infra note 74. Similarly, a category based on enforcing already-rendered judgments would seem to be one in which the plaintiff would almost always prevail. Losses in negotiable instrument cases would also seem to be abnormally small for several reasons. First, production of the negotiable instrument itself ordinarily offers the holder a certain number of significant procedural advantages so that "[i]f the validity of signatures is admitted or proved ... a plaintiff producing the [negotiable] instrument is entitled to payment if the plaintiff proves entitlement to enforce the instrument . . unless the defendant proves a defense ...." U.C.C. § 3-308 (1999). Moreover, because claimants on negotiable instruments often can qualify as holders in due course, defenses raised are likely to be ineffective since holders in due course take free of many such defenses.

In April 2000, the U.S. Department of Justice reported on a survey of state courts comprised of 75 counties. That survey revealed an average win rate for contracts cases of 62\%. Bureau of Justice Statistics Bulletin 1 (April 2000), available at http://www.ojp.usdoj.gov/bjs/pub/press/ctvlc96.pr.

The difficulty with the federal and state surveys of contracts cases and the average win rates is that, as Eisenberg points out, the success rate can vary tremendously even in "a single traditional doctrinal area, such as tort . . . across its many subcategories." Eisenberg, supra, at 355. The generalized win rates in contract are not useful because they are not indicative of what the win rate would be in promissory estoppel cases. Each subcategory of contracts would have its own win rate. See id. at 355, 357 (pointing to wide variations among subcategories of torts ranging from $25 \%$ to $72 \%$ ). Thus, the overall contract win rates in trials for plaintiffs suing in state or federal courts may not be indicative of the win rate for promissory estoppel claimants. The fact that promissory estoppel claimants might prevail less often than in other contract actions may mean that the cases brought are often weak cases.

In this Article, the data show that if only cases on the merits are considered, the percentage of wins out of the total number of cases (after moot and ir- 
The failure of promissory estoppel empirical scholarship to control for various qualitative factors of a promissory estoppel claim contributes to another deficiency, which helps account for the premature announcement of promissory estoppel's demise. In looking narrowly only at whether promissory estoppel claims as a whole succeed as a way of judging the success of the theory, such scholarship has ignored an important tenet of law and economics scholarship: that rules and doctrines should be interpreted instrumentally in terms of the prospective welfare effect of legal rules. ${ }^{49}$ By failing to control for qualitative factors in assessing the success of promissory estoppel claims, such scholars have made it difficult to assess what the welfare effects of enforcement or nonenforcement of a promissory estoppel claim would be in particular types of cases. Without such welfare effect assessments, the losses by themselves do not tell us very much since one cannot determine whether the losses foster optimal results.

If qualitative factors and efficiency consequences are accounted for, and a model of how parties bargain utilizing theories of welfare maximization, uncertainty, and sunk costs is used, then the results of the promissory estoppel cases may be rationalized more easily. ${ }^{50}$ If economic analysis is used to evaluate particular types of wins and losses, it appears that the cases do not support a generalized conclusion that promissory estoppel is a dead letter. Instead, the results support a more nuanced analysis. Plaintiffs tend to win claims when a positive result will enhance an efficient outcome, while plaintiffs tend to lose cases when a positive outcome for the plaintiff would be inefficient. ${ }^{51}$ Claimants lose in precisely those cases in which enforcement would fail to maximize "net social benefits" 52 and would have negative welfare effects.

relevant cases and nine categories of weak cases are subtracted) is $25.9 \%$, a not insubstantial win rate.

49. Goetz \& Scott, supra note 9, at 1264

50. At one level, this argument-that the results of the case law-can be rationalized in efficiency terms is a purely descriptive or explanatory one. At a second level, the argument that current results typify efficiency norms also contains a normative line of reasoning that future cases should be decided to further the efficiency goal. See Randy E. Barnett, A Consent Theory of Contract, 86 ColuM. L. REV. 269, 277 (1986) (explaining efficiency as a prototype of a "standards-based" theory "which evaluate[s] the substance of a contractual transaction to see if it conforms to a standard of evaluation that the theory specifies as primary").

51. In seeking to explain the rules of promissory estoppel case law in efficiency terms, this Article follows the tradition of Professors Goetz and Scott who declined to opine "on the extent to which economic efficiency is a dominant or merely subsidiary element in explaining the development of common law doctrine in general" and focused on "a relatively narrow segment of legal doctrine against some underlying economic optimality considerations." Goetz \& Scott, supra note 9 , at 1265 n. 17 .

52. Id. at 1264 . 
For example, one category of cases in which promissory estoppel claims routinely fail involves promises in which the reliance has preceded the promise. ${ }^{53}$ If one looks at such a case merely as a "loss" for a promissory estoppel claimant and aggregates that loss with others, the true significance of the case will remain obscure. If welfare effects are accounted for, however, the costly consequences of enforcing such promises become apparent. Enforcement of a promise where the promisee has relied before any promise was made would not increase welfare effects. Promisors would have to go to great lengths to protect themselves in the event that someone were to rely on a promise yet unmade. Making the promisor responsible for reliance that he did not solicit and could not control would be inefficient. Finally, it would encourage overinvestment by promisees. Because of the moral hazard problem, promisees would be investing without any indication that the promisor would benefit from such reliance. ${ }^{54}$

Conversely, one category of cases in which courts are apt to grant recovery involves opportunistic behavior by promisors. ${ }^{55}$ Enforcement of promises in such cases would achieve increased gains from trade by controlling opportunistic behavior in cases where private control of such behavior might be more costly than a lawsupplied rule. 56

To determine whether the announcement of promissory estoppel's demise is premature, this Article suggests that an empirical reexamination of a significant body of case law is needed. By controlling for a variety of qualitative factors, such a study would illuminate the viability of promissory estoppel as a theory of recovery in contracts when cases involving certain factors are ignored.

The results detailed in this Article show that promissory estoppel claims succeed at significant rates ${ }^{57}$ when demonstrably weak claims are subtracted. Several substantive conclusions can be drawn from this study. Most importantly, it seems as if promissory estoppel is, in fact, a viable theory of recovery and that Hillman and DeLong are wrong in claiming that promissory estoppel is a dead letter. The data also show that courts deciding promissory estoppel claims are still grappling with appropriate boundaries between bargain and reliance and with what role each doctrine should play in contract law. This Article provides an efficiency explanation for seemingly disparate results. Finally, the data also seem to suggest that lawyers have brought demonstrably weak promissory estoppel

53. See DeLong, supra note 18, at 982 n.128(3); see also cases cited infra note 86 .

54. Goetz \& Scott, supra note 9, at 1279-80 (discussing the danger of overinvestment in reliance by promisees because of the moral hazard created by full compensation to the promisee).

55. See infra Part III.A.

56. See Kostritsky, Bargaining, supra note 37, at 671.

57. See infra Tables I-IV, showing the success rates. 
claims. ${ }^{58}$ Low win rates amongst demonstrably weak claims may indicate that the pendulum has swung too far and promissory estoppel has become unmoored from its roots.

Other conclusions from the study are methodological in nature. First, the data suggest that it may not be possible to draw meaningful conclusions from generalized win/loss rates without making qualitative judgments about the viability of the claim in the case.59 Second, the study demonstrates the trickiness of interpreting win/loss rates and offers some cautionary guidelines on how to interpret such data. Finally, it demonstrates the difficulty of assembling and interpreting win rates without a specific hypothesis to prove. ${ }^{60}$

Part II of this Article describes the results of my study. It describes how the data were collected and documents the results of the study. It explains how the instant results differ from Hillman's results and explains any methodological differences between the two studies. Part II of this Article reexamines Hillman's study in detail and compares the win rates found in Professor Hillman's study with the win rates found in this study. Such a comparison serves as a basis for challenging the conclusions he draws from such data. Part III focuses on a group of winning and losing promissory estoppel cases as a means of identifying factors important to a successful claim and suggests that there is in fact a place for promissory estoppel in contract law, although it is not the place of dominance first proposed by Gilmore. Rather, when promissory estoppel is applied in commercial contexts, the success or failure of the claim depends on whether enforcement would promote efficient behavior in the bargaining context. Part IV outlines the conclusions of the study and suggests further topics for empirical research.

58. Hillman alludes to "the tenuous nature of many of the claims in the multitude of cases in which promissory estoppel failed," but also argues that such losses may demonstrate hostility to the promissory estoppel cause of action. Hillman, supra note 31, at 596. This Article disagrees, arguing that losses amongst weak claims do not provide a sound basis for concluding that courts reject the cause of action. See infra Part III.C.

59. Although these conclusions are geared to the promissory estoppel cases, they might apply to any empirical scholarship.

60. E-mail from Ronald J. Coffey, Professor of Law, Case Western Reserve University School of Law, to Juliet P. Kostritsky, Professor of Law, Case Western Reserve University School of Law (July 14, 2000) (on file with author). As Professor Coffey explains 'WWin' and 'loss' are not going to be serviceable, because ... there are different kinds of wins and losses depending on what your hypothesis(es) is (are)." Id. 


\section{MethodolOGY}

\section{A. The Data Set}

The research examines five years (1990-1994) of recent promissory estoppel cases. ${ }^{61}$ I selected 1990 as the start of the study because of prior scholarship documenting the success of promissory estoppel in earlier years. ${ }^{62}$ This study is comprised exclusively of state cases $^{63}$ and does not include federal cases. From prior research in the area, ${ }^{64} \mathrm{I}$ have found that federal cases, which often involve mainly federal statutes, such as a violation of federal age discrimination laws, append the promissory estoppel claims as afterthoughts.

The selection of this five-year data bank of cases serves several goals. It encompasses a database large enough to ensure statistically significant results. In addition, and perhaps more importantly, the selection results in an overlap with at least one of the years examined by Professor Hillman (1994), but goes back earlier in time. I was particularly interested in including earlier years of promissory estoppel in the study since Hillman's and DeLong's studies seemed to indicate a retrenchment from earlier years of promissory estoppel success reflected in such famous cases as Hoffman v. Red Owl Stores, Inc. ${ }^{65}$ and Esquire Radio \& Electronics v. Montgomery Ward \& Co. 66

\section{B. Win/Loss Rates: How to Count}

Empirical methodology depends on a classification of tried cases $^{67}$ as either "wins" or "losses" for a claimant. 68 The identifica-

61. My LEXIS search generated an enormous number of references to completely unrelated cases because of the reference to "Section 90" in the search. Because of that, the research assistants then generated a list of "case matches" by printing out the cites and eliminating those cases having nothing to do with contracts or promissory estoppel. For each year, a list of case matches was then generated and each of those cases was printed out.

62. My second aim in selecting these dates for the study was to have some temporal overlap with Professor Hillman's study (i.e., 1994). See Hillman, supra note 31.

63. The database of cases looked at all cases in the "combined state cases" library on Lexis.com generated by search terms "promissory estoppel or section 90" as well as by limiting dates after 12/31/89 and before 01/01/95.

64. See Kostritsky, New Theory, supra note 28.

65. 133 N.W.2d 267 (Wis. 1965). "The Red Owl case might be called the 'the high water mark' in the development of promissory estoppel." EDWARD J. MurPhy ET AL., STUdies In CONTRACT LAW 428 (1997).

66. 804 F.2d 787 (2d Cir. 1986). This case was discussed in Kostritsky, New Theory, supra note 28, at 924-25.

67. This methodology was used in the famous empirical work of Baxter, Priest, and Klein, which focused on "the rates of success that plaintiffs enjoy for those cases that are resolved at trial." Eisenberg, supra note 48, at 337. Of 
tion of wins and losses is complex since there are, of course, many meanings of the words "win" or "success." For example,

judgment for the plaintiff may be a "defeat" if the plaintiff expended more resources obtaining the judgment than the value of the judgment itself. Conversely, the plaintiff can claim success even if a court dismissed its claim if the litigation convinced the defendant to accede to the plaintiff's wishes. ${ }^{69}$

While admitting to some of the subtleties in the meanings of wins and losses, focusing on only two objectively verifiable meanings of a win can bring certainty to the meaning of outcomes involving promissory estoppel. These include: a win in which the plaintiff "survive[s] an opposing motion"70 and a win for the plaintiff on the merits.

Since an establishment of win and loss ratios was required, my study first had to identify a list of assumptions for classifying wins and losses. A complicated issue involved deciding whether a "win" includes only wins on the merits or also includes wins in which the promissory estoppel claimant survives an opposing motion. At one level, the answer seems simple. If the promissory estoppel plaintiff survives an opposing motion and defeats the defendant's motion for summary judgment, the plaintiff has not won on the merits. The court's decision in such cases merely means that the case will proceed. ${ }^{71}$

course, such a data set ignores an important segment of cases that are resolved before a trial. It should be noted that only $3 \%$ of cases are actually tried in the courts. The selection of tried cases from the aggregate has generated a theory about how the cases are selected for trial. George L. Priest \& Benjamin Klein, The Selection of Disputes for Litigation, 13 J. LEGAL STUD. 1 (1984). Professors Baxter, Priest, and Klein argue that the cases brought to trial are "not a random sample of the mass of underlying cases." Eisenberg, supra, at 337.

The "selection effect" posits that because of the non-random nature of cases selected for trial and because the "cases that tend to be clear for either the plaintiff or defendant... settle relatively quickly," the cases that are left are the more difficult ones. Id. This Article argues that the data here show that even weak cases that one would have thought would not have been brought to trial are in fact being tried. Therefore, the cases here may be closer to a random sample since plaintiffs' lawyers seem to be bringing relatively weak cases to trial. Contrary to Baxter, Priest, and Klein's argument that only the most difficult cases would be tried, while other cases would be settled before trial, the promissory estoppel data seem to evidence a contrary trend.

68. All decisions were classified for each year they were reported, regardless of prior or subsequent decisions. This decision was necessary because if one declined to count decisions in a year because they were subsequently modified, one could never get an accurate count since every decision could potentially be reversed and one could never have finality.

69. Hillman, supra note 31 , at 588 .

70. Id. at 589. The plaintiff could withstand a motion to dismiss, a motion to strike, or a motion for summary judgment.

71. My civil procedure colleagues argued for this restrictive definition. 
Several arguments support broadly classifying wins to include wins not on the merits. First, the narrow restriction of promissory estoppel "wins" to wins on the merits seems to result in a sample bias. By excluding cases in which the plaintiff wins on a motion (such as surviving a motion for summary judgment or defeating a defendant's motion to dismiss), a large number of promissory estoppel cases would be excluded.72 Second, wins should be broadly classified because the granting of a defendant's motion for summary judgment on the plaintiff's promissory estoppel claim results in a "loss" for promissory estoppel. Thus, the counter of that "loss" should be classified as a promissory estoppel "win" as it is a defeat for the party who would have preferred to have the matter decided on summary judgment or a motion to dismiss against the promissory estoppel claimant.

The strongest argument for liberalizing the definition of "win" to include prevailing against an opponent's motion is that a contrary classification system ignores the nature of a promissory estoppel claim. Exclusion from the win category of cases in which the plaintiff survives an opposing motion made by the defendant to dismiss the case or to move for summary judgment means that the only way a plaintiff can prevail on a pretrial motion would be by successfully prevailing on a motion for summary judgment. Yet, for necessarily fact-intensive promissory estoppel claims it is hard to imagine cases where the plaintiff could convince the court, as a matter of law, that it should prevail as there are no factual issues to contest.

In contrast, it would seem that it would be fairly easy to prevail on a motion for summary judgment with some other categories of contract cases. If a creditor sues on a defaulted student loan with a promissory note, presumably the government or whoever holds the student loan would likely prevail on a motion for summary judgment since there are no defenses that the defaulting student can raise. ${ }^{73}$ Alternatively, if there is a sale of goods in excess of $\$ 500$ and no written memorandum and no written confirmation exists, it would seem that one party should be able to prevail on the Statute of Frauds defense without actually going to trial. ${ }^{74}$

72. In my study, there were a total of 774 cases over a five-year period. Of that number, 239 cases were classified as "wins." Of these cases, 99 were wins on the merits and 140 were wins involving prevailing on a motion, usually by surviving a defendant's motion for summary judgment or motion to dismiss. Each judgment entered is an independent event. In one year a promissory estoppel claim may win and yet may lose in a subsequent year. Tallied together, the cases constitute a wash with one win and one loss. Not counting the win in the year in which it occurred would ignore relevant data. As long as wins and losses are each counted consistently, the results should be accurate.

73. Student loans are presumed not to be dischargeable in bankruptcy, and will only be discharged upon the debtor's showing of an "undue hardship." See 11 U.S.C. $§ 523(a)(8)$ (1994); Rifino v. United States, 245 F.3d 1083, 1087-89 (9th Cir. 2001).

74. U.C.C. section 2-201 (1998) requires a written memorandum for the 
In promissory estoppel cases, however, because factual issues are so closely intertwined with the cause of action, it is hard to imagine the plaintiff prevailing on a motion for summary judgment. Thus, to the extent a large number of cases come up at the preliminary level, the exclusion of all cases in which the plaintiff succeeds by opposing an opponent's motion means that the only way a plaintiff can prevail in a pre-trial context is by prevailing on a motion for summary judgment, which will be almost impossible to do. Accordingly, by limiting wins to wins on the merits and excluding wins in which the promissory estoppel claimant survives an opposing motion (motion to dismiss; summary judgment), one would in effect be restricting wins to wins following a bench trial or jury verdict or an affirmance of such a verdict. Yet, many cases never result in a full trial and it would seem somewhat arbitrary to exclude the pre-trial verdicts even though they are not wins on the merits..$^{75}$

Because the classification issue is a difficult one, however, this study segregates the data ${ }^{76}$ and breaks down the cases into two categories of wins: wins on the merits and wins not on the merits. I have separated these figures and aggregated them as well in order to calculate wins on the merits and overall wins (including not on the merits) in a variety of ways. For each year, I have segregated the number of wins on the merits from the number of total wins. The wins on the merits category includes cases in which the plaintiff

sale of goods in excess of $\$ 500$. In 2001 , the American Law Institute approved a new version of U.C.C. section 2-201 raising the dollar amount to $\$ 5000$. National Conference of Commissioners on Uniform State Laws, Amendments to Uniform Commercial Code, Article 2-Sales (2001). The National Conference of Commissioners on Uniform State Laws has not yet approved the proposed changes to Article 2. Id.

75. In fact, a call to the Clerks of Court for the Cuyahoga County Court of Common Pleas (Cleveland, Ohio) and the Ohio Eighth District Court of Appeals revealed that nearly all of the cases in which the plaintiff prevails on a preliminary motion disappear, and there is no further judicial disposition. Presumably, a percentage of these cases are settled on terms favorable to the plaintiff. Omission of all such preliminary judgments for the plaintiff, because they are not judgments on the merits, would result in a distortion of the data by omitting cases in which the plaintiffs were able to obtain relief as a result of their promissory estoppel claims. See also Hillman, supra note 31, at 588.

76. In order to be able to respond to and perhaps ultimately to even challenge Professor Hillman's conclusions, I felt it necessary to replicate his study's methodology in as many ways as possible by replicating his coding conventions and changing the study only to accomplish specific objectives of my own. As one of my colleagues explained, I should walk in the shoes of the coder. In some cases, as in the classification of wins, where I made a modification, I pursued two parallel analyses, one using Hillman's approach and one using my own modified category. For example, I expanded the category of wins to include survival of an opposing motion. Where I did so, I was also careful to pursue a parallel analysis using Hillman's more restrictive definition of "win" to include only wins on the merits. In cases where I felt that Professor Hillman's approach needed modification, I have attempted to explain the rationale for modifying the methodology. See infra Part II.C. 
prevailed in a judgment by jury verdict, bench trial, or summary judgment by appellate court affirmation of the bench verdict or the jury verdict. The category of total wins would include wins on the merits as well as cases in which the plaintiff prevailed by opposing a defendant's motion for summary judgment or motion to dismiss on the grounds of promissory estoppel. If the defendant moved for summary judgment or a dismissal, the plaintiff opposed the motion on promissory estoppel grounds, the plaintiff prevailed on that motion, and the court, in considering the motion, discussed promissory estoppel, then that result would be classified as a promissory estoppel win, though not a promissory estoppel win on the merits. ${ }^{77}$ The study collected data on the percentage of total wins including those not on the merits relative to the total number of successful and unsuccessful cases.

\section{Other Categories}

The study also tracked and accounted for those cases in which the promissory estoppel claimant lost the promissory estoppel claim but won on another cause of action. ${ }^{78}$ In such cases, the court reaches the conclusion that while the promissory estoppel claim will not succeed, on the same set of facts, the plaintiff wins on another cause of action, which may be either totally unrelated (e.g., age discrimination) or related (e.g., breach of contract claim).

The study also developed criteria for identifying and excising moot or irrelevant cases from the total number of cases examined. In "moot" cases, the court renders a decision without ever reaching the merits of the promissory estoppel claim. A case was deemed "irrelevant" when neither litigant advanced a promissory estoppel claim, but the court discussed the cause of action either in passing, or in comparison to a claim that had been advanced. ${ }^{79}$

"Unsettled" cases are those in which the promissory estoppel claim is still alive but unsettled. Usually, these cases are on appeal and the appeal does not discuss promissory estoppel. Promissory estoppel was in the complaint or in the plaintiff's opposing motion to defendant's motion for summary judgment and the court is concerned with something totally unrelated (i.e., effect of res judicata) and the promissory estoppel claim is still potentially vital but we

77. If a court affirmed a jury verdict or a bench trial on something unrelated and said that while there was no promissory estoppel there was a contract, the study would not consider that a win.

78. Such cases are classified as "No P/E but" in Table I. For further discussion of the "no promissory estoppel but" category, see infra Table I.

79. The study also developed criteria for identifying and excising moot or irrelevant cases from the total number of cases examined. In "moot" cases, the court renders a decision without ever reaching the merits of the promissory estoppel claim. A case was deemed "irrelevant" when neither litigant advanced a promissory estoppel claim, but the court discussed the cause of action either in passing or in comparison to a claim that had been advanced. 
have no idea whether it will ultimately prevail.

The study assumed that each court level of a win or loss would occur in a single year. ${ }^{80}$ However, there were complicating factors. Sometimes the same level court would rehear a case in a single year. If the same level court in a single year changes an opinion, the study counts only the later case. If the same level court in a single year issues a second opinion with no change in the later opinion, the study counts only the earlier one.

\section{Controlling for Qualitative Factors in Outcomes}

The most critical issue of methodology, which has been neglected in the current empirical work on promissory estoppel is qualitatively controlling for various characteristics of contracts opinions. Without controlling for these characteristics of the promissory estoppel opinions, it is difficult to interpret the significance or to draw meaningful conclusions from the data. Because the "win and loss" calculations used in the current empirical studies of promissory estoppel do not identify particular characteristics of the cases, they are not very serviceable when used in a generalized fashion. The need to control for such factors demonstrates the trickiness of using win rates to reach conclusions about the strength of promissory estoppel by solely counting outcomes. Controlling for such factors helps this Article facilitate a greater understanding of the case outcomes. To account for such factors and to make case outcomes more meaningful the win/loss ratio should be calculated differently than is done in current empirical studies. Instead of simply identifying the win/loss ratio based on the percentage of successful promissory estoppel cases out of the entire aggregate of relevant cases, this Article argues that the win ratio should be calculated only after accounting for certain factors.

Some of the cases that involve a "loss" by the plaintiff probably should not have been brought in the first place because the case was weak and the "loss" in such a case does not indicate much about the viability of a colorable claim. ${ }^{81}$ Accordingly, this Article argues that the way to account for the qualitative factors is to make subtractions from the entire aggregate of losses if the cases involve: (1) a fatal procedural error, ${ }^{82}$ (2) illegality, ${ }^{83}$ (3) preemption, ${ }^{84}$ (4) D’Oench $\mathrm{Du}$ -

80. See supra note 72 (explaining that each win or loss is considered an independent event).

81. In some ways the difficulty of interpreting a loss on a promissory estoppel claim demonstrates "the elusiveness of doctrine in the common law contract system." E-mail from Peter A. Alces, Professor of Law, William and Mary Law School, to Juliet P. Kostritsky, Professor of Law, Case Western Reserve University School of Law (July 26, 2001) (on file with author). In order to distill and refine the doctrine, one must take the datum of the loss and analyze it in conjunction with the particular factors of the case. Only in this manner can one make inferences about the contours of the doctrine of promissory estoppel.

82. See, e.g., Polk v. Denver Dist. Ct., 849 P.2d 23 (Colo. 1993) (finding a 
$h m e,{ }^{85}(5)$ reliance before the promise, ${ }^{86}(6)$ promise not broken, ${ }^{87}(7)$

trial court's refusal to permit a defendant to add the affirmative defense of promissory estoppel, after three years of litigation was not reversible error); Whalen v. United Air Lines, 851 P.2d 251 (Colo. Ct. App. 1993) (ruling that a promissory estoppel claim, which had gone unadjudicated during a prior unsuccessful federal lawsuit, was nevertheless barred by res judicata); Revelle v. Home Sites, Ltd., 431 S.E.2d 405 (Ga. Ct. App. 1993) (finding that an alleged promise that a residential development would be an "upscale subdivision" was insufficient to create a justiciable controversy); Woller v. Sandoz Nutrition Corp., No. C9-93-1177, 1993 Minn. App. LEXIS 1165 (Nov. 30, 1993) (barring a plaintiff from raising promissory estoppel for the first time on appeal); Gilbert v. Trumbull County Bd. of Educ., No. 92-T-4761, 1993 Ohio App. LEXIS 4813 (Sept. 30, 1993) (finding that a promissory estoppel claimant's failure to exhaust his quasi-judicial, administrative appeals barred his efforts to relitigate those claims in court); Bowsher v. Bowsher, No. 91 CA 19, 1992 Ohio App. LEXIS 3544 (June 30, 1992) (finding that the defendant introduced no evidence at trial to support his promissory estoppel claim); Cleveland Asbestos Abatement v. Parma City Sch. Dist. Bd. of Educ., No. 59706, 1992 Ohio App. LEXIS 318 (Jan. 30, 1992) (presuming the propriety of arbitration proceedings upon finding that the promissory estoppel claimant's failure to submit the record of the arbitration proceedings rendered it impossible to determine whether or not an arbitrator had incorrectly decided the claim); Christopher Di Stefano \& Assocs. v. City of Alvin, No. 01-91-01291-CV, 1993 Tex. App. LEXIS 2535 (Sept. 6, 1993) (finding that the plaintiff waived any promissory estoppel claim by failing to raise it on appeal)

83. See, e.g., Belin v. West, 864 S.W.2d 838 (Ark. 1993) (finding that adjudication and enforcement of an alleged promise to make the plaintiff a pastor would require an impermissible inquiry into church policy and violate the First Amendment); Stanfield v. Huskey, No. 03A01-9209-CV-345, 1993 Tenn. App. LEXIS 238 (Mar. 30, 1993) (finding that a mayor's promise to reimburse a painter for the cost of several murals was void as ultra vires absent a proper resolution by the city commission).

84. See, e.g., Browning v. Navistar Int'l Transp. Corp., No. 91AP-1286, 1992 Ohio App. LEXIS 2621 (May 19, 1992) (plaintiff was denied right to add promissory estoppel claim because of close relation to contract claims currently being arbitrated and contract claims preempted by NLRA); see also Digliani v. City of Fort Collins, 873 P.2d 4 (Colo. Ct. App. 1993) (finding a plaintiff's claim for breach of a promise to provide a safe working environment was preempted by the Colorado Workers' Compensation Act); Palmieri v. Int'l Union of Operating Eng'rs, Local No. 478A-C-D-E Pension Fund, No. CV 87-0329, 1993 Conn. Super. LEXIS 3288 (Dec. 10, 1993) (noting that promissory estoppel claims are preempted by ERISA and finding, irrespective of any preemption, that plaintiff could not demonstrate any detrimental reliance on the erroneous statement that his pension rights had vested).

85. See, e.g., FDIC v. Moreau, No. 358731, 1992 Conn. Super. LEXIS 154 (Jan. 9, 1992) (finding that all of plaintiff's affirmative defenses to the FDIC's foreclosure action, including promissory estoppel, were barred by D'Oench, $D u$ hme \& Co. v. FDIC, 315 U.S. 447 (1942), and 12 U.S.C. $§ 1823(\mathrm{e})$ ).

86. The "reliance before promise" category would also include actions where the promise was actually revoked before the reliance action occurred. See, e.g., Wolf v. Metro. Life Ins. Co., No. C-910081, 1992 Ohio App. LEXIS 406 (Feb. 5, 1992) (where plaintiff was specifically told to cut ties with other insurance companies, reliance on prior practice of permitting such practice not covered by estoppel principles); see also King v. Nev. Elec. Inv. Co., No. 94-4122, 1995 U.S. App. LEXIS 15369 (10th Cir. June 21, 1995) (finding unreasonable any reliance 
bad employee conduct,88 (8) bad faith by promissory estoppel claim-

on a proposed joint venture agreement, after the parties ceased efforts to further negotiate the joint venture); Podolan v. Idaho Legal Aid Servs., Inc., 854 P.2d 280 (Idaho Ct. App. 1993) (finding that reliance by promissory estoppel claimants preceded employment by defendant and thus could not provide a basis for the defendant's liability); Cambridgeport Sav. Bank v. Boersner, 597 N.E.2d 1017 (Mass. 1992) (finding that a borrower's obligation to pay monthly interest charges preceded a bank's promise to fund those payments from the outstanding loan principal); Lavoie v. Safecare Health Serv., Inc., 840 P.2d 239 (Wyo. 1992) (finding that the plaintiff's voluntary upgrade of his facilities preceded the defendant's vague remarks about possibly employing his services); $c f$. Wolf v. Metro. Life Ins. Co., No. C-910081, 1992 Ohio App. LEXIS 406 (Feb. 5, 1992) (finding unreasonable any purported reliance on an outdated policy statement when the plaintiff was informed that he could be terminated for continuing to sell insurance for competing insurance companies); see also cases cited in DeLong, supra note 18, at 982 n.128(3).

87. See, e.g., Sauntry v. N.W. Bell Tel. Co., No. C2-91-2294, 1992 Minn. App. LEXIS 415 (Apr. 28, 1992) (finding that the company's actions did not violate employee handbook since promise to give treatment for chemical dependency was fulfilled, and plaintiff-employee's conduct in using position to assist drug dealing boyfriend was wrongful and just grounds for discharge); Bellian v. Bicron Corp., No. 92-G-1695, 1992 Ohio App. LEXIS 6364, at *19-20 (Dec. 18, 1992) (rejecting promissory estoppel claim where alleged promises of lifetime employment had not been broken since plaintiff still employed, albeit at a lower salary); Oliver-Coogler v. Toledo Edison Co., 611 N.E.2d 474 (Ohio Ct. App. 1992) (finding that even if defendant's drug policy created an actionable promise, promissory estoppel claim failed because the plaintiff did not prove that the defendant violated the policy when terminating her for drug use); see also Langley v. Prescott Travel, Nos. 61384, 61558, 1992 Ohio App. LEXIS 5845 (Nov. 19, 1992) (finding that an alleged promise that the plaintiff could keep his commissions schedule did not alter his at-will employment status and noting that the plaintiff admitted that he had been fully compensated).

88. See, e.g., Burrell v. Carraway Hosps. of Ala., Inc., 607 So. 2d 193 (Ala. 1992) (finding an employee's expectation that he would not be fired for performing private work while on duty to be unreasonable since handbook reserved right of employer to terminate employee with or without cause); Sauntry, 1992 Minn. App. LEXIS 415 (finding no circumstances upon which to support a promissory estoppel claim by former employee who had admittedly used her position with the phone company to assist her drug-dealing boyfriend in evading law enforcement); Seta v. Reading Rock, Inc., 654 N.E.2d 1061 (Ohio Ct. App. 1995) (finding that an employer's drug and alcohol policy did not create a promise of job security for an employee who admittedly abused drugs); Hayes v. Cleveland Pneumatic Co., 634 N.E.2d 228 (Ohio Ct. App. 1993) (finding against a promissory estoppel claimant with cocaine addiction who was fired when he had expressly agreed that he was employed at-will and there had been no promise to let claimant take a medical leave of absence); Lake v. Wolff Bros. Supply, Inc., No. 63959, 1993 Ohio App. LEXIS 5352 (Nov. 10, 1993) (affirming the trial court's judgment against an employee who had been fired for mismanagement and finding statements that the plaintiff would be employed "forever" were too vague to alter the at-will employment relationship); Shepard v. Ltd. Inc., No. 92AP-1440, 1993 Ohio App. LEXIS 2939 (June 8, 1993) (finding that a vague statement that the plaintiff would not be fired if his job performance improved did not give rise to a promissory estoppel claim when the plaintiff's job performance only grew steadily worse); Smith v. Cincinnati Milacron, Inc., No. C920102, 1993 Ohio App. LEXIS 6513 (Mar. 17, 1993) (finding no enforceable 
ant, 89 or (9) a disclaimer. ${ }^{90}$ When those subtractions are made, ${ }^{91}$ the

promise not to fire an employee who desired to use his sick days to cover a term of incarceration); Anderson v. Morning View Care Ctr., No. 92AP060043, 1993 Ohio App. LEXIS 177 (Jan. 8, 1993) (finding that a former employee, who voluntarily resigned following a reprimand for patient abuse, could not successfully advance a claim of promissory estoppel); Washington v. Cleveland Clinic Found., No. 61556, 1992 Ohio App. LEXIS 6249 (Dec. 10, 1992) (finding that an employer's statement that the plaintiff's employment status would be reevaluated once her criminal drug-trafficking charges were resolved did not constitute a promise of continued employment); Marshall v. Youngstown Hosp. Ass'n, No. 91 C.A. 195, 1992 Ohio App. LEXIS 6138 (Dec. 2, 1992) (finding that an employer's statement that the plaintiff might not be fired if he admitted that he had vandalized a restroom did not create an actionable promise); Wolf v. Metro. Life Ins. Co., No. C-910081, 1992 Ohio App. LEXIS 406 (Feb. 5, 1992) (finding any purported reliance on an outdated policy statement, after the plaintiff was informed that he could be terminated for continuing to sell insurance for competing insurance companies, was unreasonable).

89. See, e.g., Wota v. Blue Cross \& Blue Shield of Colo., 831 P.2d 1307 (Colo. 1992) (finding promissory estoppel claim unsuccessful where plaintiff knew the insurance policy did not cover a particular procedure and any reliance was based on wishful thinking and additional coverage that plaintiff knows is a mistake does not constitute a promise to continue added coverage); see also DeJean v. United Airlines, Inc., 839 P.2d 1153, 1157 (Colo. 1992) (affirming the appellate court's refusal to equitably estop the defendant from enforcing a full release, signed by the plaintiffs in exchange for their being rehired, based upon representations that allegedly occurred prior to the release's execution); S. Gen. Constr. v. Cathedral Stoneworks, 32 Va. Cir. 277 (1993) (excusing the lowestbidding subcontractor's non-performance upon finding that the general contractor's delay in accepting the bid was an attempt to secure a more favorable deal).

90. See, e.g., Sheppard v. Maumee Valley Girl Scout Council, No. L-91-304, 1992 Ohio App. LEXIS 2732 (May 29, 1992) (handbook disclaimer that it did "not constitute an employment contract" precluded reasonable belief or reliance by employee on handbook's disciplinary procedures and promissory estoppel failed); Williams v. Cap Gemini Am., Inc., No. 62953, 1992 Ohio App. LEXIS 4604 (Sept. 10, 1992) (finding no enforceable oral promise when the laterexecuted employment contract stated clearly that the plaintiff was an at-will employee); Weese v. Davis County Comm'n, 834 P.2d 1 (Utah 1992) (finding it unreasonable to rely on policy of merit pay increases in county's employee handbook when it disclaimed any contract existed and stated clearly that the practice could be discontinued at any time and promise to continue to pay merit increases would be ultra vires); see also Lawson v. Sci. Applications Int'l Corp., 894 F. Supp. 378 (D. Colo. 1995) (finding that vague statements that employees would be treated fairly did not constitute an actionable promise when the plaintiff signed two conspicuous disclaimers, which stated that he was employed solely at-will); Lake v. Wolff Bros. Supply, Inc., No. 63959, 1993 Ohio App. LEXIS 5352 (Nov. 10, 1993) (finding that vague statements that plaintiff would be employed "forever" were insufficient to alter the employment relationship when the plaintiff signed a clear statement that he was an at-will employee); Washington v. Cleveland Clinic Found., No. 61556, 1992 Ohio App. LEXIS 6249 (Dec. 10, 1992) (noting that the employee handbook, upon which the plaintiff allegedly relied, contained a clear statement that the handbook could not be considered an employment contract).

91. My student coders and I actually coded for a total of 17 factors. Of course, the exact categories of excluded cases are subject to debate. The entire list of factors that were coded included: 
denominator of cases shrinks, thereby increasing the percentage of cases in which promissory estoppel prevails.

Identification of these relatively verifiable factors ${ }^{92}$ offers the means to determine a correlation between the presence of those factors and the success and lack of success of the promissory estoppel claimant in the case law. Wins or losses by themselves are too general to be of any interest. On the other hand, the identification of generalized win/loss rates together with separately identifiable win/loss rates, without the presence of those factors, provides a basis for arguing that plaintiffs' win/loss rates differ depending on the absence or presence of certain factors. To the extent that those factors correspond with fundamental flaws in a plaintiff's case, one can point to relatively "stronger" win ratios in the absence of those factors.

The purpose of identifying such factors is to explain losses on promissory estoppel claims in terms that are not related to a court's generalized hostility to the cause of action or in which the loss seems to be explicable in terms of a factor unrelated to the merits of the promissory estoppel claim. By identifying these factors, and isolating them from the results by running win/loss rates without such cases, this Article seeks to pierce through the generalized claim that promissory claims rarely succeed, since such generalizations as to the acceptability or the non-acceptability of a claim are not apt to be particularly useful. To guide future lawyers in determining whether to file or how to defend a claim, it would be far more useful to determine the particular factors associated with higher or lower win

\footnotetext{
1. Losses because of Statute of Frauds or Parol Evidence Rule

2. D'oench Duhme

3. Claims against governmental entities

4. Weak claims

5. Bad faith by promisee

6. Promise not broken

7. Reliance before the promise

8. Promise itself unenforceable, illegal or enforcement of contract would be illegal or violate the statute

9. Fatal procedural error

10. Other-not apparently weak

11. Insufficient data: no facts or no discussion of P/E claim. Appeal relates to unrelated matter: injunction, jury trial, new evidence, judge's conflict of interest

12. Miscategorized as P/E claim

13. Plaintiff suffered no loss or injury or no detrimental reliance

14. Disclaimer (e.g., employee handbook)

15. Sunk costs or solicited by promisor

16. Employment case with bad employee

17. Effect of written contract on P/E claim: contract on subject so court says no $\mathrm{P} / \mathrm{E}$ claim, no $\mathrm{P} / \mathrm{E}$ claim if trying to do an end run around the contract, or contract followed by an oral promise

92. Although these data are non-scalar, and thus not precisely quantifiable, these factors are relatively objectively identifiable in the case law.
} 
ratios.

Once these objective and verifiable factors can be identified in losing cases, it becomes possible to argue that the plaintiffs' losses can be explained by those factors, rather than the courts' generalized resistance to promissory estoppel claims. Clearly, the preemption, D'Oench Duhme, and "fatal procedural error" categories all involve defenses by the defendants that do not involve the merits of the plaintiff's claim. Rather, because of some procedural flaw by plaintiff's lawyer or by some unrelated law that preempts promissory estoppel, or altogether precludes the raising of the claim (such as the D'Oench Duhme doctrine), the plaintiff loses. The loss is not because of a flaw in the plaintiff's promissory estoppel claim as such but because the court cannot hear the case. In cases involving the illegality claim, even if the promise were to be enforced, it would be illegal to enforce it. Thus, even if the promises were made and reliance induced, the court would not be able to enforce it because enforcement of the promise would actually be illegal. Thus, one could argue that no matter how meritorious the promissory estoppel claim, the court is disabled from enforcing the promise that is the foundation of the plaintiff's case. Promissory estoppel claims involving categories seven and eight based on the bad faith of the promissory estoppel claimant or bad employee conduct, respectively, are comprised of cases in which it seems apparent that the promissory estoppel claim should not be allowed to prevail because of the fundamentally bad behavior of the claimant. Finally, in categories five and six, reliance before the promise and promise not broken, the loss seems explicable in terms of the weakness of the cases. Thus, losses in these cases speak not so much to the hostility of the courts to the cause of action, but instead to the plaintiffs' lawyers' confusion in pleading promissory estoppel in such cases.

This Article calculated the overall win percentage of all "successful cases" subtracting out only moot and irrelevant cases (30.8\%). It then calculated the percentage of "successful" to "not successful" cases for all cases, leaving out "moot" and "irrelevant" cases and cases in which the plaintiff prevailed on another cause of action but lost on promissory estoppel (34.9\%). Finally, I added the percentage of "successful" cases and "not successful but" cases to the total number of cases subtracting only "moot" and "irrelevant" cases $(42.5 \%) .{ }^{93}$

Subsequently, I ran the same calculations for all wins, including wins not on the merits subtracting out cases involving the nine categories. ${ }^{94}$ Finally, I used only wins on the merits and made the same calculations of all wins, including wins not on the merits. ${ }^{95} \mathrm{I}$

93. See Table I.

94. See Table II.

95. See Table III. 
then subtracted the nine factors and re-ran the success ratios, 96 because, as stated above, in at least some cases denominated as "losses" the promissory estoppel claimant fails due to factors having little to do with the merits of his or her claim. If the lawyer misses the relevant statute of limitations, and the promissory estoppel claimant loses, that loss really says very little about the viability of promissory estoppel as a theory or its acceptability in a particular jurisdiction. It makes sense to subtract these types of cases from the total losses. When these subtractions are made, the resulting percentages would presumably give some qualitative sense of how likely promissory estoppel is to win when the claim is somewhat viable.

It may be difficult to draw useful conclusions from generalized win/loss rates. However, if one states an accompanying hypothesis with particularity, then it may be possible to draw conclusions about what cases win and lose. 97 Perhaps the proposition might be that the courts deciding promissory estoppel claims subscribe to a particular view of the reliance required for a plaintiff to prevail. 98 That view could be supported either by the language of the court or by compiling data on the type of reliance evident in the case, ${ }^{99}$ though the court did not expressly advert to this matter. One could then align the cases to determine what type of reliance was required for a winning claim. The proposition or hypothesis might be a broader one: that the courts are hostile to the promissory estoppel cause of action or to the theory itself. In some sense, Hillman has argued that his empirical data support this last, broader thesis. 100

The difficulty with using generalized win/loss rates to support a proposition as broad as one stating that the low win ratio shows the demise of promissory estoppel as a cause of action in the courts is that wins or losses by themselves do not tell us very much. As one commentator has explained, the win rates tell us "something about the set of adjudged cases, and not much about the underlying mass of disputes and cases." 101 If the plaintiff fails to put on any evidence at all or misses the statute of limitations for contract actions, a loss of a promissory estoppel claim might tell us very little at all about how successful a plaintiff with a colorable promissory estoppel claim is likely to be in a particular jurisdiction, or whether the jurisdiction accepts the theory. A case involving a complete failure of proof or an untimely complaint, together with a "loss" might tell us only that if a plaintiff misses a relevant statute of limitations it will lose or that

96. See Table IV.

97. See Coffey, supra note 60.

98. Id.

99. Id.

100. Hillman, supra note 31 , at 588-96.

101. Kevin M. Clermont \& Theodore Eisenberg, Do Case Outcomes Really Reveal Anything About the Legal System? Win Rates and Removal Jurisdiction, 83 CoRnell L. REV. 581, 589 (1998). 
a plaintiff will lose if it fails to offer any evidence at all. Thus, it would be hard to aggregate those "losses" into a category with other "losses" and to draw conclusions out of an aggregation of such failures about promissory estoppel claims in general. Instead, the losses might tell us more about the performance of the plaintiff's lawyer or about the requirements of pleading than the viability of promissory estoppel claims in a particular jurisdiction. The loss would be unlikely to tell us whether courts had "soured" on the theory or were hostile to the cause of action itself. Thus, without an expressly stated particularized hypothesis, it might be difficult to prove that a particular case is a win or loss in a meaningful way. 
TABLE I

OVERALl Win PERCENTAges 102

\begin{tabular}{|l|c|c|l|}
\hline & Wins & Total & \multicolumn{1}{|c|}{ Percent } \\
\hline All Cases & & & \\
\hline Succ./Total - Moot and irrel. & 239 & 774 & $\begin{array}{l}0.308786^{* *} \\
(10.64)\end{array}$ \\
\hline Succ./Not succ.+Succ. & 239 & 684 & $\begin{array}{l}0.349415^{* *} \\
(7.88)\end{array}$ \\
\hline Succ.+No, but/Total - Moot and irrel. & 329 & 774 & $\begin{array}{l}0.425065^{* *} \\
(4.17)\end{array}$ \\
\hline Employment & & & \\
\hline Succ./Total - Moot and irrel. & 107 & 383 & $\begin{array}{l}\left(8.279373^{* *}\right. \\
(8.64)\end{array}$ \\
\hline Succ./Not succ.+Succ. & 107 & 339 & $\begin{array}{l}\left(6.315634^{* *}\right. \\
(6.79)\end{array}$ \\
\hline Succ.+No, but/Total - Moot and irrel. & 151 & 383 & $\begin{array}{l}\left(4.394256^{* *}\right. \\
(4.14)\end{array}$ \\
\hline Non-Employment & & & \\
\hline N.E.Succ/N.E.Total - moot and irrev.. & 132 & 391 & $\begin{array}{l}0.337596^{* *} \\
(6.42)\end{array}$ \\
\hline N.E.Succ/N.E.N.S.+N.E.Succ & 132 & 345 & $\begin{array}{l}\left(4.382609^{* *}\right. \\
(4.36)\end{array}$ \\
\hline $\begin{array}{l}\text { N.E.Succ+N.E.No, but/N.E.total-moot } \\
\text { and irrel }\end{array}$ & 178 & 391 & $\begin{array}{l}\left(1.455243^{* *}\right. \\
(1.77)\end{array}$ \\
\hline
\end{tabular}

102. Table I included as wins all wins, including wins not on the merits. ${ }^{* *} \mathrm{p}<0.01$

${ }^{*} \mathrm{p}<0.05$ 


\section{TABLE II 103 \\ CASES WiTHOUT FPE, Disclaimer, BAD FAITH, BAD \\ EMPlOYEe, 104 Illegal, PREEMPTION, D'OENCH DUHME, AND PROMISE NOT BROKEN}

\begin{tabular}{|l|c|c|l|}
\hline & Wins & Total & \multicolumn{1}{|c|}{ Percent } \\
\hline Succ./Total - Moot and irrel. & 239 & 522 & $\begin{array}{l}0.457854^{*} \\
(1.93)\end{array}$ \\
\hline Succ./Not succ.+Succ. & 239 & 432 & $\begin{array}{l}0.553241^{\mathrm{t}} \\
(-2.21)\end{array}$ \\
\hline
\end{tabular}

103. The only category in which there is no statistically significant difference is in the cases that are the subject of Table II. In that case, we looked at all wins, including wins on the merits, and then subtracted out cases involving the nine weak categories. In the first category reaching a $45.7 \%$ win, the t-value shows a significance difference so the fact that the second category of success/not successful but cases plus successful cases and a win rate of $55.3 \%$ is not all that troubling. In the lower win rate $(45.7 \%)$ we are including all no promissory estoppel but cases in the total number of cases and none of those categories is classified as a win. Because a great number of no promissory estoppel but cases (classified as losses in the $45.7 \%$ category) would have been filtered out by our limiting factors, this is actually an underrepresentation of the overall success rates. For total wins/total cases-moot and irrelevant cases the $45.7 \%$ is actually a downward distortion of the actual success rate and it is still fairly high.

$104{ }^{*} \mathrm{p}<0.05$

${ }^{\mathrm{t}} \mathrm{p}>0.95$ 
TABLE III

CASES ON THE MERITS

\begin{tabular}{|l|c|c|l|}
\hline & Wins & Total & \multicolumn{1}{|c|}{ Percent } \\
\hline Succ./Total - Moot and irrel.105 & 99 & 634 & $\begin{array}{l}0.156151^{* *} \\
(17.3)\end{array}$ \\
\hline Succ./Not succ.+Succ. & 99 & 544 & $\begin{array}{l}0.181985^{* *} \\
(14.83)\end{array}$ \\
\hline
\end{tabular}

105. Note that when we look at cases on the merits and subtract out the nine categories of weak cases, the success rate percentage is calculated on the basis of the total number of cases minus the moot and irrelevant. Thus, it includes in the denominator as a loss those cases in which the promissory estoppel claim lost but the promissory estoppel claimant actually won on another theory.

$$
{ }^{* *} \mathrm{p}<0.01
$$


TABLE IV

CASES ON THE MERITS WITHOUT FPE, DISCLAIMER, BAD FAITH, Bad employee, Illegal, Preemption, D'OeNCH DUHME, AND PROMISE NOT BROKEN

\begin{tabular}{|l|l|l|l|}
\hline & \multicolumn{1}{|c|}{ Wins } & \multicolumn{1}{c|}{ Total } & \multicolumn{1}{|c|}{ Percent } \\
\hline & & & $0.259162^{* *}$ \\
Succ./Total - Moot and irrel. & 99 & 382 & $(9.41)$ \\
\hline & & & $0.339041^{* *}$ \\
Succ./Not succ.+Succ. & 99 & 292 & $(5.50)$ \\
\hline
\end{tabular}


TABLE V

\begin{tabular}{|l|c|c|c|c|l|l|}
\hline Year & $\begin{array}{l}\text { Merit } \\
\text { Wins }\end{array}$ & $\begin{array}{c}\text { Total } \\
\text { Wins }\end{array}$ & $\begin{array}{c}\text { Relevant } \\
\text { Cases }\end{array}$ & $\begin{array}{c}\text { Limited } \\
\text { cases }\end{array}$ & \multicolumn{1}{|c|}{$\begin{array}{c}\text { Merit/Total } \\
\text { Relevant }\end{array}$} & Merit/Limited \\
\hline 1990 & 15 & 46 & 154 & 63 & $\begin{array}{l}0.0974026^{* *} \\
(9.99)\end{array}$ & $\begin{array}{l}0.23809524^{* *} \\
(4.16)\end{array}$ \\
\hline 1991 & 30 & 55 & 129 & 84 & $\begin{array}{l}0.23255814^{* *} \\
(6.08)\end{array}$ & $\begin{array}{l}0.35714286^{* *} \\
(2.62)\end{array}$ \\
\hline 1992 & 16 & 37 & 100 & 59 & $\begin{array}{l}0.16^{* *} \\
(6.80)\end{array}$ & $\begin{array}{l}0.27118644^{* *} \\
(3.52)\end{array}$ \\
\hline 1993 & 18 & 47 & 119 & 80 & $\begin{array}{l}0.1512605^{* *} \\
(7.61)\end{array}$ & $\begin{array}{l}0.225^{* *} \\
(4.92)\end{array}$ \\
\hline 1994 & 20 & 54 & 163 & 94 & $\begin{array}{l}0.1226994^{* *} \\
(9.63)\end{array}$ & $\begin{array}{l}0.21276596^{* *} \\
(5.57)\end{array}$ \\
\hline
\end{tabular}

${ }^{* *} \mathrm{p}<0.01$ 


\section{E. Why My Results Differ From Professor Hillman's}

Professor Hillman generated his own database comprised exclusively of promissory estoppel cases decided in federal and state courts from 1994-1996. Hillman's study examined 362 federal and state cases that were analyzed and coded for his study. ${ }^{106}$ Hillman based his conclusions on his empirical study of win/loss rates ${ }^{107}$ in his database of cases. According to Hillman, those cases demonstrate a "remarkable lack of success of promissory estoppel claims in reported decisions,"108 "judicial souring on the theory," 109 and a "judicial resistance to the theory." 110

The power of Hillman's thesis that the courts rarely accept promissory estoppel claims ${ }^{111}$ depends on acceptance of his methodology for measuring win rates for plaintiffs at trial.112 Accordingly, to reach the conclusion that promissory estoppel claims rarely succeed, Hillman restricts plaintiff wins to those in which the plaintiff wins on the merits at the state trial court or federal district court level, 113 since he views wins on the merits as the more useful measure of success. ${ }^{114}$ However, as stated above, a study that relies exclusively on calculations based on wins and losses on the merits neglects powerful arguments for including non-merit wins as plaintiff wins.

Hillman's thesis on the demise of promissory estoppel also depends on his acceptance of the "so-called 50 percent hypothesis." 115 That thesis posits that plaintiffs will win 50\% of tried cases. Promissory estoppel success rates are judged a failure by Hillman's im-

106. Hillman, supra note 31 , at 582 n.15. Hillman calls it "the first comprehensive empirical study that demonstrates promissory estoppel's limited role." Id. at 581 .

107. The study of win rates is a "form of analysis [that] is as much art as science ...." Clermont \& Eisenberg, supra note 101, at 592.

108. Hillman, supra note 31 , at 583.

109. Id. at 596 .

110. Id.

111. Of course, it is important to remember that only a small percentage of $3 \%$ of filed cases ever goes to trial. Priest \& Klein, supra note 67 , at 2 . Thus, the tried cases that are the subject of Hillman's study and my own are not representative of the entire group of disputes.

112. Of course, the success rates of cases that actually go to trial may be significantly different than the "mass of underlying disputes," and it may be difficult to draw conclusions about the whole mass of promissory estoppel from the litigated cases. The tried cases thus represent a "biased sample." Clermont \& Eisenberg, supra note 101 , at 588.

113. Hillman compares a $9.70 \%$ win on the merits in promissory estoppel claims in trial court levels to a $90.30 \%$ loss on the merits in the same courts as the most accurate measure of the success of promissory estoppel claims. Hillman, supra note 31 , at 590 tbl. 1.2.

114. Id. at 590 .

115. Eisenberg, supra note 48, at 338 . 
plicit assumption that unless promissory estoppel claimants prevail in at least $50 \%$ of the cases (using only cases on the merits as wins) that the plaintiffs' success rate must be adjudged a failure. However, this assumption that any win rate below $50 \%$ is a failure is incorrect for two reasons. First, since success rates can vary across subcategories of cases ${ }^{116}$ and the data on win rates for contracts cases collected in federal or state databases do not code for promissory estoppel, it is arguable that promissory estoppel success rates could be below $50 \%$ without supporting a conclusion that the theory itself is dead. Second, the relevant success rate percentages are likely to be below $50 \%$ when there are "misperceptions about the prevailing standard of decision." 117 In addition, "the 50\% prediction is wrong in theory and empirically incorrect." 118

Finally, and most importantly, Hillman fails to integrate his data about the importance of reliance and fails to control for various other qualitative factors of the cases into his conclusions about the success or failure of promissory estoppel claims in the courts. He makes two separate claims: (1) that promissory estoppel claims have been notably unsuccessful in the courts, and (2) that the presence or absence of reliance affects the success of a promissory estoppel claim. Yet, because it is not possible to draw generalized conclusions about the success or failure of promissory estoppel as a theory without a particularized examination of the factors present in claims that fail, Hillman's explanation about the high loss rate as a reflection of a souring on the cause of action ${ }^{119}$ is misguided. Thus, for example, if an examination of the losing cases indicated that plaintiffs were losing even when the elements of promissory estoppel appeared to be clearly present, then it would be logical to infer that courts were hostile to the cause of action. Similarly, if a close examination of the case law revealed courts stating that they no longer accepted the theory of promissory estoppel, such losing cases could be counted in various jurisdictions to support a theory of the demise of promissory estoppel in those jurisdictions. However, losses-even a great number of promissory estoppel losses-do not necessarily indicate a demise of the theory per se. Instead, if a large number of

116. Id. at 351-52. Tort success rates range from $25-60 \%$. Id.

117. Clermont \& Eisenberg, supra note 101, at 590.

118. E-mail from Theodore Eisenberg, Professor of Law, Cornell University Law School, to Juliet P. Kostritsky, Professor of Law, Case Western Reserve University School of Law (Nov. 1, 2000) (on file with author). Professor Eisenberg cites Steven Shavell, Any Frequency of Plaintiff Victory at Trial is Possible, 25 J. LEGAL STUD. 493 (1996), in which Shavell explains that based on a model of asymmetric information, "[I]t is possible in this model for the cases that go to trial to result in plaintiff victories with any probability." Id. at 494. The plaintiffs' win rates may thus depart from the 50\% hypothesis where the tried cases are those in which a "[t]rial results when a defendant finds the plaintiff's demand excessive ...." Id. at 495; see also Eisenberg, supra note 48 (providing empirical evidence contradicting the $50 \%$ hypothesis).

119. Hillman, supra note 31, at 596. 
cases lack the basic elements necessary for a claim to succeed, losses by themselves cannot form the basis for a proposition about the demise of the theory.

This Section will attempt to explain why my results differ from those in Hillman's study and detail the methodological as well as analytical differences between the two studies. Specifically, it argues that if the data is properly presented and interpreted, then Hillman is wrong in concluding that promissory estoppel is a generally unsuccessful theory.

\section{Data Set and Methods}

The data set itself is not significantly different from Professor Hillman's. Hillman based his conclusions on a review of 362 reported state and federal cases during a two-year period (1994-1996). This study expanded the data set to include a five-year period of cases (1990-1994) and a total of 760 cases. Presumably, the expansion of the study to include three additional years should not change the results or conclusions.

Unlike Professor Hillman's study, this study was comprised exclusively of state cases. As previously noted, I had found in federal cases that the promissory estoppel claims were often appended as afterthoughts and proved generally of less importance than in state law cases. The limitation of this study to state cases might or might not make a difference in the overall outcomes and win rates. However, as there is no indication in Hillman's study of a different overall win rate in state and federal cases, I have assumed that the win rates would not be significantly different in federal cases. I am planning to do a separate study to test this hypothesis.

The most substantial changes in the two studies concern this study's inclusion of a separate category of wins to include "wins not on the merits" in which the promissory estoppel claimant wins by surviving an opposing party's motion. Since this study tracked the category of "wins on the merits" separately, presumably the data detailing wins that are based on "wins on the merits" should be comparable to Hillman's own data tracking wins on the merits. The second substantial change involves the accounting for various qualitative characteristics of the opinions in the win/loss rates. ${ }^{120}$

\section{2. $\quad$ Interpreting the Data}

Because the data sets in both studies are comparable in many ways, the explanation for the differences in conclusions drawn from the data must lie elsewhere. The two studies reach divergent conclusions about the viability of promissory estoppel as a theory because Hillman's study looked at win/loss rates without controlling for various characteristics of the cases. The lesson of this study is

120. See infra Part III. 
that an overall data set cannot be used to generate win rates that are meaningful, unless the study also controls for a variety of specific characteristics that might tell us something about the relative strength of a promissory estoppel claim. Because Professor Hillman's study does not identify or control for a variety of such characteristics in determining the win rate or interpreting the meaning of the win rates for promissory estoppel, his conclusion that the data measurements prove that "promissory estoppel may no longer be, if it ever was, a significant theory of recovery,"121 may not be correct.

It should be noted that Professor Hillman does examine one characteristic in the cases in great detail: the reliance factor. $\mathrm{He}$ finds that a court's discussion of reliance figures prominently in those cases in which the plaintiff prevails on the merits or survives an opponent's motion. ${ }^{122}$ Conversely, Hillman notes that in claims that fail, "the use of defective reliance" 123 is frequently a factor. ${ }^{124}$

However, despite Hillman's recognition of the importance of the reliance factor in the cases, he uses his findings on reliance primarily to undermine the promise theorists who had suggested that reliance was no longer a necessary element in promissory estoppel claims. Because Hillman focuses on debunking that view, he does not pursue the wider implications of the results of his data showing the importance of reliance. Had Hillman been willing to look at the results of his data emphasizing the importance of reliance from a different vantage point, he might have drawn different conclusions from the data.

A deeper, though unexplored, significance of Hillman's finding on the continuing importance of reliance is that in assessing and compiling win rates on promissory estoppel claims and in distilling the significance of the doctrine of promissory estoppel from such data, it is important to identify factors that might correlate with the weakness of the claim. As previously stated, without controlling for such qualitative characteristics, one will only be able to compile generalized win/loss rates. Without a qualitative analysis of the cases, it is hard to draw conclusions from the data about the ability of a plaintiff with a colorable claim to prevail. Instead, they tell us a great deal about the cases that were brought. This study concludes that the entire data set of promissory estoppel cases reveals significant weaknesses in the claims. Thus, it is premature to claim that there is hostility to the cause of action and a demise in the acceptance of the theory merely because there are a significant number of promissory estoppel losses.

121. Hillman, supra note 31 , at 619 .

122. Id. at 597 (The data "shows the high rate of courts discussing reliance as a reason for success on the merits (93.10\%) and for surviving an opposing motion (56.14\%).”).

123. Id. at 600 .

124. Id. 
The difficulty inherent in interpreting win rates indicates the importance of having a carefully crafted hypothesis to use in determining win and loss ratios. ${ }^{125}$ This Article suggests that a working methodology to use in these cases is that it is important to disaggregate from the overall loss category those claims that contain factors correlating with significant weaknesses and then to analyze win/loss rates while accounting for such factors.

\section{The Case LaW: Providing a Means of Further INTERPRETING THE DATA}

Accounting for qualitative characteristics in the cases is an important first step in being able to draw distinctions in the outcomes of cases. Once these qualitative characteristics are accounted for, it is possible to draw more nuanced conclusions about wins and losses amongst promissory estoppel cases. The data show that there is a place for promissory estoppel in Contract, and that promissory estoppel claims are succeeding at not insignificant rates if cases involving certain characteristics are ignored. ${ }^{126}$ Promissory estoppel has not fulfilled Gilmore's prediction that it would dominate Contract, ${ }^{127}$ but it is holding its own.

In order to go beyond limited conclusions about the accuracy of the win/loss rates and to better understand the nature of the role that promissory estoppel is playing in the cases and in Contract, this Article suggests that three additional factors in the case law should be examined: opportunism, the bargain element, and weakness in the claim. These factors do not correspond with the nine factors accounted for in this Article's empirical study of the cases in Part II. The factors identified here are broader conceptual categories and would be hard to justify as verifiable, and for those reasons they were not separately accounted for in the empirical data. Often, courts do not even cite these factors. ${ }^{128}$ Nevertheless, these three factors are important because when considered together they offer a broader rationale for the case law outcomes and for several of the categories cited in this Article's empirical study. ${ }^{129}$

125. See supra note 60.

126. See supra Tables I-IV.

127. Gilmore, supra note 1 , at 72 .

128. The exception is the presence of the bargain element, which some courts cite explicitly as a reason for a promissory estoppel claimant's failed cause of action. See infra text accompanying notes 168-87. The fact that courts do not cite these factors, however, does not take away from their significance since in economic analyses "law consists in whatever principles best explain the outcomes, not the express reasoning, in judicial decisions." Jody Kraus, The Methodological Commitments of Contemporary Contract Theory 10, Working Paper No. 01-2 (May 2001), available at http://papers.ssrn.com/paper.taf?ab stract_id=269975.

129. See infra text accompanying notes 137-203. 
That rationale suggests that promissory estoppel case law results can be explained from an efficiency perspective. The scope of promissory estoppel in Contract and the success or failure of a promissory estoppel claim are determined by a desire to promote optimal interactions between a promisee and a promisor ${ }^{130}$ and to promote efficient reliance. ${ }^{131}$ In some cases, in order to maximize gains from trade and promote efficient reliance, courts deciding promissory estoppel claims impose liability in the form of a law-supplied default rule making the promisor liable for the precontractual reliance costs of the promisee. ${ }^{132}$ For example, courts seem to take account of opportunism in determining the success or failure of a promissory estoppel claim. ${ }^{133}$ Such an approach seems efficient since imposing a default liability rule to control opportunistic behavior ${ }^{134}$ and maximize joint gains through the doctrine of promissory estoppel would save the parties the costs of alternative means of protecting against such opportunistic behavior. The existence of such a rule thereby promotes mutual trust 135 and increases overall gain. Where the implication of a liability default rule, however, is not necessary to maximize gains from trade or would actually foster inefficient reliance, there is no need for the law to intervene through a lawsupplied precontractual liability rule and the promissory estoppel claimant will likely lose. This would be the case where the parties have actually achieved a bargain on their own or the claim is weak.

This issue-whether and when the law should supply a liability rule to promote efficiency-has important ramifications for the de-

130. Goetz \& Scott, supra note 9 , at 1266.

131. See, e.g., Craswell, supra note 37, at 490-95. "This was the central insight of Goetz and Scott's 1980 article, which introduced the concept of efficient reliance...." Id. at 489. "Thus the efficient level of reliance is determined by a sort of cost-benefit analysis, analogous to the 'Learned Hand' test for defining the efficient level of precautions in a negligence case." Id. at 491.

132. The basic justification for default rules is to supply terms that most parties would have included in their contract were it not for high transaction costs. "The Coasean Contractual Theory ... says that because it is costly to bargain around the law, courts should imply standard form or 'default' contract terms that mimic the terms that most parties would have explicitly included in their contracts." Jason Scott Johnson, Opting In and Opting Out: Bargaining for Fiduciary Duties in Cooperative Ventures, 70 WASH. U. L.Q. 291, 293 (1992); see also Charles J. Goetz \& Robert E. Scott, The Limits of Expanded Choice: An Analysis of the Interactions Between Express and Implied Contract Terms, 73 CAL. L. REV. 261 (1985). For a critique of the traditional hypothetical bargain justification for default rules, see Jules L. Coleman et al., A Bargaining Theory Approach to Default Rule Provisions and Disclosure Rules in Contract Law, 12 HARV. J.L. \& PUB. POL'y 639, 644 (1989).

133. See cases cited infra note 137.

134. For an important examination of the dangers of opportunism in preventing trust formation during precontractual negotiation, see G. Richard Shell, Opportunism and Trust in the Negotiation of Commercial Contracts: Toward a New Cause of Action, 44 VAND. L. REV. 221 (1991).

135. Id. 
bate about whether there has in fact been a demise of promissory estoppel, as claimed by the empirical scholars. Because empirical scholars have focused on counting wins and losses rather than on the particular nature of the cases in which a plaintiff won or lost, that question has been obscured in the empirical literature to date. A win or loss by itself does not give enough data for a reader to determine whether intervention would be optimal or efficient. By focusing on the nature of cases that plaintiffs win or lose, as well the bargaining framework, it becomes possible to see the cases differently, not simply as an undifferentiated mass of wins and losses but rather as losses and wins that can be rationalized into an explanatory theory. ${ }^{136}$

\section{A. The Problem of Opportunism}

\section{If Opportunism Present, Promissory Estoppel Victory Likely}

The presence of opportunistic behavior by defendants appears to play an important role in winning promissory estoppel claims. ${ }^{137}$

136. In studying case outcomes and seeking an explanatory theory (efficiency) that can unify the cases, this Article typifies the tendency of law and economics to view law as

consist[ing] in whatever legal principles best explain the outcomes, not the express reasoning, in judicial decisions .... Because the law is constituted by case outcomes, the legal theorist's job is to provide the best available principled account of those outcomes, without regard to the doctrinal statements judges offer in defense of their decisions.

Kraus, supra note 128 , at 10.

137. Although the empirical study did not isolate this factor per se, because of verifiability concerns, it is a significant factor in the cases in which promissory estoppel claimants prevailed. See Skycom Corp. v. Telstar Corp., 813 F.2d 810 (7th Cir. 1987) (denying summary judgment for defendant because of promissory estoppel issues in which plaintiff turned over its valuable rights to acquire a third firm to defendant in reliance on defendant's promises to compensate and on tentative agreement by defendant to acquire plaintiff's assets; after acquisition failed, defendant unjustly enriched); Esquire Radio \& Elecs. Inc. v. Montgomery Ward \& Co., 804 F.2d 787 (2d Cir. 1986) (Plaintiff prevailed where its actions in buying and maintaining stock for defendant helped defendant to hedge against uncertainty as to demand for parts supply.); Exch. Oil \& Gas Corp. v. Great Am. Exploration Corp., 789 F.2d 1161, 1164 (5th Cir. 1986) (Promissory estoppel was appropriate where promisor agreed to pay drilling expenses while it was unclear whether well would be valuable and then reneged on promise to share proportionate expenses once it became clear that the well was worthless, and defendant "gained a substantial advantage, to the detriment of Exchange of being able to wait until the drilling was completed and with geological hindsight decide whether it wished to risk any venture capital."); Werner v. Xerox, Corp., 732 F.2d 580 (7th Cir. 1984) (where defendant's promises that plaintiff would become off-load producer caused plaintiff to invest in equipment and plaintiff's actions reduced uncertainty for defendant by providing an off-site production facility should in house production not work out, plaintiff's reliance was reasonable); Shelley v. Trafalgar House Pub. Ltd. Co., 918 F. Supp. 515 (P.R. 1996) (Defendants failed to secure motion for summary judgment on 
plaintiffs' promissory estoppel claim where defendants induced plaintiffs to acquire additional land for resort and defendant benefited from plaintiffs' land acquisition because it enabled defendant to keep financing for the deal alive with a bank which had insisted on such land acquisition; defendant could hedge while deciding whether to proceed with the deal.); Genin, Trudeau \& Co. Ltd. v. Integra Dev. Int'l, 845 F. Supp. 611 (N.D. Ill. 1994) (Licensor entered into an oral agreement with plaintiff but refused to execute agreement because of litigation with prior licensee while urging the plaintiff to proceed as if agreement in effect; defendant hedged on the uncertainty of how the lawsuit with prior licensee would be decided and negotiated with alternate licensees while assuring itself that plaintiff would incur sunk costs and be available should it become necessary.); Atl. Paper Box Co. v. Whitman's Chocolates, 844 F. Supp. 1038 (E.D. Pa. 1994) (Defendant, which was in the process of negotiating sale of its company to third party that manufactured boxes in house, nevertheless encouraged plaintiff to keep manufacturing capacity in reserve to accommodate defendant's need for boxes; defendant thereby allowed to hedge on uncertainty by providing itself with a backup should its deal with the third party fail.); Computer Sys. of Am., Inc. v. IBM, 578 F. Supp. 558. (D. Mass. 1983) (where plaintiff relied on defendant's intent to lease computer by customizing computer and those actions reduced uncertainty for defendant by guaranteeing it would have the necessary computer equipment in the spring even if defendant's deal with IBM could not produce one in time); Oates v. Teamster Affiliates Pension Plan et al., 482 F. Supp. 481 (D.C. Ct. 1979) (where defendants acted opportunistically in securing plaintiff's help by promises to protect his pension in order to achieve an affiliation between plaintiff's former labor group and the Teamsters and then reneging following the affiliation, plaintiff secured summary judgment on promissory estoppel); Zeman v. Lufthansa German Airlines, 699 P.2d 1274 (Alaska 1985) (Where defendant assured plaintiff that lease agreement would be signed and induced plaintiff to accelerate construction and to make modifications and plaintiff's actions shielded defendant from uncertainty about availability of housing for its employees, summary judgment was inappropriate for defendant and plaintiff could pursue promissory estoppel if plaintiff's reliance substantial.); Curran Assocs. v. Iroquois Gas, 1992 Conn. Super. LEXIS 3678 (Jan. 11, 1993) (Plaintiff recovered on promissory estoppel and other claims when defendant refused to honor promise that if plaintiff continued work on pipeline and finished project, defendant would pay and defendant benefited by having work done.); Chrysler Corp. v. Quimby, 144 A.2d 885 (Del. 1958) (following death of president of automobile dealership, defendant persuaded plaintiff to acquire remaining stock of dealership by promising dealership to him, plaintiff expended significant funds to acquire such stock, plaintiff's actions benefited defendant by getting widow a buyout at no cost to defendant, and permitted defendant to hedge while it sought most capable franchisee); White House Inc., v. Winkler, 415 S.E.2d 185, 188 (Ga. Ct. App. 1992) (holding where defendant wanted production to commence, promised manufacturer that guarantees of payment would be forthcoming, promised that manufacturer would be paid, and defendant wanted benefit of having production commence without becoming personally liable on the guaranty, material fact on promissory estoppel claim established); Christensen v. Intelligent Sys. Master Ltd. P'ship, 399 S.E.2d 495, 496 (Ga. Ct. App. 1990) (finding for plaintiff on estoppel though defendant not bound contractually, where defendant's letter of intent prompted plaintiff to permit defendant to take over management of subsidiary that was subject to sale, plaintiff advanced the subsidiary $\$ 600,000$, and defendant's operation of the subsidiary gave it the opportunity to observe the operation of the subsidiary firsthand and to reduce uncertainty about the potential acquisition); Quake Constr., Inc. v. Am. Airlines, Inc., 537 N.E.2d 863, 868 (Ill. App. Ct. 1989) (holding where plaintiff subcontractor refused to supply license numbers of other 
subcontractors without a signed agreement and defendant sent a letter of intent and solicited substantial steps, inappropriate to dismiss complaint on promissory grounds); Cellucci v. Sun Oil Co., 320 N.E.2d 919, 926 (Mass. App. Ct. 1974) (holding where defendant's promise to plaintiff during the midst of negotiations that plaintiff was not free to entertain competitor's offer because defendant had already bought the plaintiff's property, defendant would be estopped to deny the offer when plaintiff relied by terminating negotiations with competitor); United Elec. Corp. v. All Serv. Elec., Inc., 256 N.W.2d 92, 96 (Minn. 1977) (holding where general contractor promised to issue checks jointly to subcontractor and supplier to insure that the supplier would be paid and supplier relied on promise to furnish supplies, promissory estoppel applies to protect the supplier); McNeill \& Assocs., Inc., v. ITT Life Ins. Corp., 446 N.W.2d 181, 187 (Minn. Ct. App. 1989) (holding where defendant promised plaintiff he would not be terminated for cause and defendant benefited by plaintiff's buying failing company at defendant's urging estopped defendant from denying promise not to terminate); Commercial Bank of Gideon v. Bien Co., 830 S.W.2d 503, 506 (Mo. Ct. App. 1992) (holding where construction company and owner had a contract and construction company got financing from plaintiff, which refused to lend unless owner made checks payable jointly to bank and construction company and owner benefited by securing financing for contractor and thereby getting building built, promissory estoppel applied); Peck v. Imedia, Inc., 679 A.2d 745 (N.J. Super. Ct. App. Div. 1996) (where defendant recruited free lance employee to be full-time employee and defendant got benefit of further screening employee by having her complete rush project, plaintiff employee stated promissory estoppel cause of action).

Several excellent examples of opportunistic behavior exist in the realm of employment. For example, when employees undertake significant forbearances in reliance on an employer's promise of job security, a law-supplied default rule seems appropriate. In Cashdollar v. Mercy Hospital of Pittsburgh, 595 A.2d 70, 71 (Pa. Super. Ct. 1991), plaintiff sold his home in Virginia, resigned from a similar position at another hospital, and relocated his pregnant wife and twoyear-old son to Pittsburgh. After sixteen days, the plaintiff was terminated. Id. at 72. Affirming the plaintiff's jury verdict, the appellate court found that the plaintiff's detriments were above and beyond those normally considered by atwill contracts, and that promissory estoppel was proper. Id. at 73-74. In another case, a teacher relying on a promise that his seniority would not be jeopardized took a five-year leave of absence. Chopp v. Indep. Sch. Dist. 706, Nos. C7-90-2068, C8-90-1351, 1991 Minn. App. LEXIS 96, at *2-3 (Feb. 5, 1991). On returning to work, defendant school board ruled that plaintiff teacher's seniority had not in fact been preserved. Finding that the plaintiff justifiably relied on defendant's assurance, damages based on promissory estoppel were affirmed. Since the defendant (through its agent, the superintendent) "knew, or should have known" that plaintiff would rely on its response, the application of promissory estoppel was appropriate. Chopp, 1991 Minn. App. LEXIS 96, at *4. Other, more pronounced examples of opportunistic behavior by employers illustrate the value of a default liability rule. In Camillo $v$. Wal-Mart Stores, Inc., 582 N.E.2d 729, 731 (Ill. App. Ct. 1991), plaintiff assistant-manager at a retail store was denied a year-end bonus after working through the Christmas season. Although his evaluations seemed to provide no warning of imminent termination, defendant terminated plaintiff one day before he would have been eligible for a substantial bonus. Finding that the promise of a large bonus induced plaintiff to stay on the job (working in excess of fifty-four hours a week), and that "[t]he requirements of honesty and fair dealing" mandated finding for the plaintiff, the Illinois Court of Appeals reversed a jury ruling and awarded damages to plaintiff based upon promissory estoppel. Id. at 734 . 
Before looking at the specific cases, this Section will first examine the general problem of opportunism in a bargaining context and offer an efficiency rationale for the case results. ${ }^{138}$

The bargaining process is likely to be characterized by opportunistic behavior. ${ }^{139}$ Controlling that behavior is important because doing so will increase gains from trade. ${ }^{140}$ Otherwise, parties will devote valuable resources to controlling such behavior and the danger of opportunism, if unchecked, will dissipate gains from trade. ${ }^{141}$

Controlling opportunism presents tricky contracting problems for a variety of reasons. First, the parties suffer from bounded rationality ${ }^{142}$ and cannot anticipate all ways in which opportunism will arise. As a result, they cannot develop complete, explicit contracts to deal with opportunism. Even if they could deal with the problem more generally, by agreeing to cooperate to maximize profits, that kind of clause presumably would not work because of the opportunistic behavior that is likely to occur. ${ }^{143}$ Thus, the problem cannot be solved privately ex ante by a generalized clause agreeing to cooperate. Finally, many transactions are likely to be accompanied by the investment of transaction specific assets. Such sunk costs further increase the possibility of opportunistic behavior by the party who has not invested himself or herself but who is soliciting the investment of assets to increase information about the investing party, thereby reducing uncertainty about that party, or about the feasibility or terms of a bargain. Such sunk costs also interfere with private solutions to problems that may arise in the bargaining phase. ${ }^{144}$

138. Once an efficiency rationale is adverted to, which can explain particular outcomes, the aggregate number of wins or losses becomes less important than how the losses and wins comport with efficiency goals.

139. Williamson explains opportunism as "self-interest seeking with guile." Oliver E. Williamson, The Mechanisms of Governance 6 (1996) [hereinafter Williamson, Mechanisms]. Traditional classical economists were slow to admit the importance of opportunism and dangers of opportunism. The new institutional economists have viewed the control of opportunism as an opportunity for gain and have sought to explain institutional organization itself as a function of controlling such dangers. Id. at 47-48.

140. Id. at 93 .

141. Oliver E. Williamson, Economic Institutions of CAPitalism 63 (1985) [hereinafter WiLliamson, InstiTUTiONs]. Williamson warns that a failure to control opportunism is important "lest the gains be dissipated by costly subgoal pursuit." Id.

142. Bounded rationality refers to "behavior that is "intendedly rational, but only limitedly so." WILLIAMSON, INSTITUTIONS, supra note 141, at 45 (emphasis deleted). Bounded rationality differs from the assumption in classical economic orthodoxy, which placed no limits on the parties' ability to foresee all contingencies and to contract accordingly.

143. Id. at 48 .

144. According to Professor Oliver Williamson, the investment of these transaction-specific assets means that the parties are "effectively transformed into bilateral supply." WiLliamson, MECHANISMS, supra note 139, at 61. For 
Once this model is adverted to, one can argue that many promissory estoppel cases involve the possibility that one party will make reassuring comments or promises in order to induce the other to make reliance investments. These investments often help to reduce one party's uncertainty about the other party or about future events, but leave the investing party vulnerable to opportunistic behavior. In such cases, at least where one can surmise that a law-supplied default rule would control such opportunistic behavior at less cost than other private devices for controlling such behavior, one could argue that promissory estoppel-in effect a liability rule-should be adopted as a least-cost alternative of controlling such behavior. If this model is understood, then many of the case outcomes can be understood as consistent with controlling opportunistic behavior, promoting efficient behavior, and maximizing gains from trade.

A series of promissory estoppel cases involve sunk costs invested by one party at the behest of another. Often these sunk costs are of particular benefit to the defendant in allowing the defendant to "hedge" pending a determination as to whether to enter into a fully contingent contract with the plaintiff, and if so, on what terms. ${ }^{145}$ The sunk costs invested by the plaintiff play an important role in reducing uncertainty for the defendant.

In these cases, the parties are often negotiating a contract, the final terms of which are under consideration. In these instances, one party often solicits sunk costs from the other party. For example, in Moore $v$. Missouri-Nebraska Express, Inc., ${ }^{146}$ the defendant leased trucks from the plaintiff. The defendant was actually in-

that reason the parties lack access to competitive partners, and that fact alone makes "unassisted market governance" problematic and calls for governance schemes to attenuate the hazards from such investments. Id. at 61-62. Because the promise theorists argued that promissory estoppel claimants could recover without demonstrating reliance or sunk cost investments, the recognition by DeLong and Hillman that courts require reliance has been seen as a retrenchment. However, the insistence on reliance as an element makes sense from an efficiency standpoint. If the promissory estoppel claimant has not relied on the promise, then the need for the law to intervene to prevent the opportunistic exploitation of such sunk costs simply does not exist. Moreover, absent such sunk costs, the parties are simply free to walk away from the transaction and reach contractual arrangements with alternative parties.

145. See Cyberchron Corp. v. Calldata Sys. Dev. Inc., 47 F.3d 39, 44-45 (2d Cir. 1995) (permitting purchaser to "hedge" pending final agreement when purchaser and supplier were negotiating the permissible weight for a computer work station, purchaser pressured supplier into starting performance "to maintain the schedule" and then terminated the contract for alternate supplier); see also Zeman v. Lufthansa German Airlines, 699 P.2d 1274, 1278-79 (Alaska 1985); Christensen v. Intelligent Sys., 399 S.E.2d 495, 496-97 (Ga. App. 1990) (finding promissory estoppel where potential purchaser permitted to take over seller's subsidiary during which time seller advanced subsidiary $\$ 1,000,000$ and purchaser had an opportunity to reduce its uncertainty about the prospective purchase).

146. 892 S.W.2d 696 (Mo. Ct. App. 1994). 
creasing its own privately-owned fleet, and this expansion made the plaintiff nervous about its future business relationship with the defendant. 147 To allay the plaintiff's fears about a possible sudden termination under the existing lease, the defendant promised to execute an amended lease containing a 365-day notice of termination. ${ }^{148}$ Based on this promise, the plaintiff continued to lease trucks to the defendant rather than find new lessees. ${ }^{149}$ The defendant never actually drafted the new lease and several months later, after acquiring enough of its own trucks to no longer require leasing from the plaintiff, the defendant canceled its lease with the plaintiff. 150

Cyberchron v. Calldata Systems Development, Inc., 151 involved similar opportunistic behavior in which the defendant solicited sunk costs from the plaintiff as a way of hedging and determining whether to contract with the plaintiff and if so, on what terms. The defendant solicited quotes for the construction of rugged computer equipment to be used in a military project, ${ }^{152}$ and began dealing exclusively with the plaintiff. Despite the absence of a written contract due to a failure to agree on a material term, 153 agents of the defendant applied a barrage of pressure on the plaintiff to begin production. ${ }^{154}$ Because the highly specialized manufacture would involve significant sunk costs, not practically salvageable for any other use, the plaintiff expressed uncertainty about whether to proceed. ${ }^{155}$ An agent of the defendant ordered the plaintiff to proceed as if there was a contract, and offered assurance that any problems would be resolved. ${ }^{156}$ Relying on the defendant's promise, ${ }^{157}$ the plaintiff began production and invested in excess of $\$ 150,000$ in materials and labor. 158 The defendant never finalized the agreement, and after entering into a contract with another supplier, declared its

147. Id. at 702 .

148. Id.

149. Id. at 702-03.

150. Id. at 703 .

151. 47 F.3d 39 (2d Cir. 1995). The trial court opinion appears in $831 \mathrm{~F}$. Supp. 94 (E.D.N.Y. 1993).

152. The defendant was a subsidiary of Grumman, which had a contract with the U.S. Marine Corps. Cyberchron, 47 F.3d at 41.

153. Id. The weight of the equipment and the penalty provisions continued to be troublesome issues. Id.

154. Id. at 44 .

155. Id.

156. Specifically, Calldata directed Cyberchron to proceed "as if the weights were approved." Id. at 45.

157. The trial court found that Calldata "assured Cyberchron ... that if it did the work, the negotiation problem could be resolved." Id. at 44 (quoting Cyberchron Corp. v. Calldata Sys. Dev., 831 F. Supp. 94, 103 (E.D.N.Y. 1993)). An agent of Cyberchron responded that "[i]f I have your assurance that we will resolve the issues in the very near future . . - - we will proceed." Id. (quoting $C y$ berchron, 831 F. Supp. at 103).

158. Id. at 46 . 
intent to terminate the relationship. 159

In Cyberchron, the defendant's solicitation of performance by the plaintiff, despite the absence of an agreement, secured a significant advantage. The defendant gained information about the plaintiff's ability to manufacture computer equipment that met the military's weight and ruggedness criteria and the plaintiff's ability to produce the units in a timely manner. As a result of the defendant's insistence on performance by the plaintiff, the defendant learned key facts: the plaintiff could not meet the weight specifications and the plaintiff's performance would not be timely. 160 The defendant then proceeded with an alternative supplier. ${ }^{161}$

Moore and Cyberchon typify opportunistic behavior during the preliminary negotiation phase. ${ }^{162}$ Opportunistic behavior may also occur in a variety of other ways involving sunk costs and uncertainty outside the context of preliminary negotiations. 163

The question in all promissory estoppel cases is the fundamental one of justifying intervention by the law in the form of a liability rule when the parties have failed to achieve a conventional bargain contract. Justifying such intervention requires a framework for determining whether, when, and why the law should supply a liability rule for precontractual negotiation. The important point to note is that in these cases involving opportunism, the law often sides with the promissory estoppel claimant and, in effect, supplies a liability rule to govern precontractual bargaining. That willingness to impose a liability rule can be justified as efficient since such intervention may be the most cost-effective means of controlling opportunistic behavior, which both parties would seek to control ex ante as a means of maximizing joint gains. Because private control arrangements may be costly, the law-supplied rule may be the most effective means of controlling opportunism and maximizing joint gain.

159. Id. at 42 .

160. Cyberchron, 831 F. Supp. at 105.

161. Id. at 105-06. The defendant had been negotiating with alternative suppliers while continuing to insist on plaintiff's performance.

162. This can occur "when the less-committed party simply exploits the part performance and breaks off negotiations." Shell, supra note 134, at 239; see also New Haven Sav. v. Common Constr., No. 100742, 1994 Conn. Super. LEXIS 2598 (Oct. 17, 1994) (rejecting bank's summary judgment motion because it attempted to speculate on whether or not it would be more profitable to complete the project or foreclose while letting the subcontractors, as junior encumbrances, carry the risk).

163. See, e.g., Robitaille v. Downey, CV-89-41810S, 1991 Conn. Super. LEXIS 3003 (Dec. 11, 1991) (holding promissory estoppel existed where claimants turned over assets worth in excess of $\$ 50,000$ in reliance on promises that liability on a note would be discharged; promisors opportunistically secured the business and the assets and then reneged on the promise of discharge). 
2. If Opportunism Absent, Promissory Estoppel Loss More Likely

The importance that controlling opportunism plays in explaining promissory estoppel outcomes can also be illustrated by looking at cases lacking opportunistic behavior. Although courts do not cite the absence of opportunism as a factor in denying a promissory estoppel claim, a number of categories associated with the promissory estoppel losses are perhaps better explained in terms of the absence of opportunism and by associated efficiency concerns.

DeLong identifies a number of categories associated with denials of promissory estoppel claims including: the presence of disclaimers, ${ }^{164}$ the withdrawal of the promise before the reliance, ${ }^{165}$ the incurring of reliance costs before the promise, ${ }^{166}$ or the absence of or ambiguity of a promise. ${ }^{167}$ These factors are often explained in terms of the failure of an element of Section 90. Thus, disclaimer of contractual liability makes reliance on assurances unreasonable and thereby defeats a Section 90 action. A withdrawal of the promise or a disavowal of the promise before the reliance similarly defeats a Section 90 recovery by making the reliance unreasonable. An ambiguous promise makes the promisee's reliance unreasonable or defeats the requirement of a promise.

All of the doctrinal categories associated with a losing claim, however, may be better explained by the fact that there is no hidden danger of opportunism and thus, no need for the law to intervene with a promissory estoppel liability rule to control opportunism and maximize gains. Nor is there any other efficiency justification for a law-supplied rule. Thus, in these cases, intervention on behalf of a promissory estoppel claimant would be inefficient.

For example, in the employment context, once a clear disclaimer is made indicating that an employee handbook is not a contract, a court should be reluctant to imply contractual protection for em-

164. See supra note 90.

165. Variety Children's Hosp. Inc. v. Century Med. Health Plan, Inc., 57 F.3d 1040, 1043 (11th Cir. 1995); Prop. Dev. Ltd. v. Sto-Kent Lanes, Inc., C.A. No. 17059, 1995 Ohio App. LEXIS 2169, at *4 (May 24, 1995).

166. Reeves v. Alyeska Pipeline Serv. Co., 926 P.2d 1130, 1138-39 (Alaska 1996); Struck v. Hackett, 668 A.2d 411, 420 (Me. 1995); Martin v. Huntington Nat'l Bank, No. L-95-077, 1995 Ohio App. LEXIS 5051, at *5 (Nov. 17, 1995).

167. See, e.g., Wilkerson v. Colorado, 830 P.2d 1121 (Colo. 1992) (holding that it is unreasonable for plaintiff to rely on promises of former governor that plaintiff would be reappointed to a new parole board when new governor retained control of the appointment process); Minneapolis Teachers Ret. Fund Ass'n v. State, 490 N.W.2d 124 (Minn. 1992) (rejecting plaintiffs' argument that when legislature set up pension fund, there was an implicit promise that it "would be maintained in an 'actuarially sound manner" contrary to history and statutory language, and no promissory estoppel action would lie); Courtney v. Kinetico Inc., No. 91-G-1640, 1992 Ohio App. LEXIS 1254 (Mar. 20, 1992) (holding that promises about the duration of a project do not constitute actionable promises guaranteeing plaintiff employment for the length of the project). 
ployees who purport to rely on vague statements of security. Implication of a default rule of liability in such cases would be inefficient because it would entail large reversal costs for employers who would devote extraordinary and nonproductive resources to avoiding liability in cases where the language clearly negated liability. Similarly, where the promise has been withdrawn before the reliance, there is no justification for the law's intervention. In fact, enforcing promises in such circumstances would provide incorrect incentives for future promisees to rely even after the promise had been withdrawn. Where the promisor himself has acted to withdraw the promise before the reliance, the law's intervention would be inefficient and thus, not cost-justified.

\section{B. If a Bargain Feasible or Present Promissory Estoppel Likely to Fail}

Another factor in the case law that determines whether a promissory estoppel claimant is successful or not is whether or not a bargain exists. ${ }^{168}$ "Many jurisdictions have developed a rule under which the existence of a bargain contract concerning a subject automatically bars any claim of promissory estoppel relating to the same subject."169 Although not all jurisdictions adopt such a broad rule, at a minimum, promissory estoppel is unlikely to succeed where the promissory estoppel claim conflicts with the formal bargain. ${ }^{170}$ The judicial reluctance to entertain promissory estoppel claims in cases where a bargain exists has been rationalized as an example of the retrenchment of promissory estoppel and its subordination to bargain. ${ }^{171}$ Yet, these case law results are perhaps better explained in efficiency terms.

If one focuses on the key issue in promissory estoppel cases, whether the law should intervene with an implied liability default rule if the parties have failed to negotiate an expressly reciprocal conventional contract, then the efficiency rationale can be uncovered in these cases dealing with the availability of a promissory estoppel claim if there is a bargain. If the issue is framed in those terms,

168. DeLong, supra note 18 , at 974 .

169. Id.; see, e.g., Gadsby v. Norwalk Furniture Corp., 71 F.3d 1324, 1333 (7th Cir. 1995) (rehearing en banc denied Jan. 29, 1996) (upholding the dismissal of promissory estoppel claim due to existence of express contract in case where plaintiff also failed to establish right under contract to post termination commissions).

170. The courts' disallowance of promissory estoppel claims in cases where a contract exists is particularly likely if the promissory estoppel claimant is trying to secure a better deal than exists under the terms of the express contract. See, e.g., Barnes v. Burger King Corp., 932 F. Supp. 1420 (S.D. Fla. 1996) (affirming summary judgment for defendant on promissory estoppel finding that plaintiff's reliance on prior oral representation as to exclusivity of franchise unreasonable when subsequent written franchise agreement clearly contradicted such representation).

171. DeLong, supra note 18, at 978-79. 
then it makes sense for a court to grant a promissory estoppel recovery where persuasive barriers to the negotiation of an explicit bargain exist, and where the court is convinced that the parties ex ante would have wanted the court to adopt a liability rule as a means of increasing gains from trade. Where the parties, however, have reached an explicit bargain, the very fact that they have negotiated a bargain seems to dictate a "no recovery" result on a promissory estoppel claim. There is no justification for the law to intervene with an implied liability default rule when the parties successfully negotiated terms of a bargain on their own. Where the parties have reached a bargained-for exchange, intervention in the form of a lawsupplied rule could be counterproductive and inefficient. It would introduce uncertainty by displacing bargained for terms and rewriting contracts entered into by the parties. It would be inefficient because it would actually increase transaction costs by creating reversal costs as future parties must undertake extra precautionary measures to ensure that courts did not apply promissory estoppel in cases where a completed bargain existed.

The relationship between bargain and promissory estoppel has been a complex one. Initially, promissory estoppel was thought to be subordinate to bargain and courts were presumed reluctant to give promissory estoppel a life of its own.172 Gradually, according to some commentators, promissory estoppel became accepted as a truly independent theory of recovery with courts evidencing a willingness to apply promissory estoppel even where a bargain existed.173 For those who viewed promissory estoppel as an independent basis of recovery that was applied even "when there is no barrier to recovery on a breach of contract theory,"174 the current disinclination of courts to apply promissory estoppel in cases where a bargain exists, or where the bargain conflicts with the promissory estoppel claim, provides further evidence of the demise and retrenchment of promissory estoppel.

Yet, if these cases are looked at in light of an economic framework and in terms of prospective effects and efficiency concerns, it

172. See Henderson, supra note 23 , at 346-47.

173. Michael B. Metzger \& Michael J. Phillips, The Emergence of Promissory Estoppel as an Independent Theory of Recovery, 35 RUTGERS L. REV. 472, 474, 551 (1983).

174. DeLong, supra note 18, at 974. Gallant v. Toledo Pub. Schs., 616 N.E.2d 1156 (Ohio Ct. App. 1992) (denying plaintiff's promissory estoppel claims because a written contract on the same subject existed). Into this category of bargains precluding promissory estoppel claims, this Article places cases involving an agreement to waive what might otherwise be a valid promissory estoppel claim. See, e.g., DeJean v. United Airlines, Inc., 839 P.2d 1153 (Colo. 1992) (promissory estoppel claim waived by subsequent agreement and trial court would not permit promissory estoppel claimants to both benefit from subsequent agreement, including reinstatement, and then attempt to reassert the promises, which had clearly been waived, without which waiver, benefits of subsequent agreement would not have been possible). 
may be that the cases do not reflect a retrenchment. Instead, the courts' struggle to resolve the inherent tension between promissory estoppel and bargain has resulted in a pattern of enforcement and non-enforcement, which can be rationalized in efficiency terms. Courts seem more willing to apply promissory estoppel where significant barriers prevent the negotiation of an explicitly reciprocal contract because, in such cases, permitting an estoppel claim may be the most efficient means of fostering reliance and increasing gains from trade. It seems appropriate to apply promissory estoppel when private bargains may be unlikely to arise and yet it would seem optimal for the reliance to be protected. ${ }^{175}$ Otherwise, if parties are denied protection, in the future more elaborate protective mechanisms would have to be devised. On the other hand, if the parties have successfully negotiated an explicitly reciprocal bargain, that would seem to indicate that barriers to the achievement of a bargain do not exist, and thus, there is no need for the law to intervene to protect reliance.

Criterion Leasing Group v. Gulf Coast Plastering \& Drywall176 illustrates one such case where it would not occur to the parties to bargain, and yet it would be important to craft a liability rule to protect one party's reliance. Gulf Coast hired a subcontractor on the basis of proof of insurance.177 For various reasons, the coverage was invalid as to that subcontractor's employees. When an employee was injured, Gulf Coast paid the claim and then sued the insurance company for reimbursement. The court held that the "promise of coverage induced Gulf Coast" to contract with the subcontractor 178 and that the promise of coverage should be enforced.

In instances like the Gulf Coast case, it would seem efficient for Gulf Coast to rely on the certificate of insurance. Gulf Coast would have had no notion that there would even be a need to bargain regarding the insurance coverage of the subcontractor. In fact, it would be an awkward case for negotiating a bargain that included guarantees regarding the insurance coverage since it is the third party, the insurance company, which issues the policy, and Gulf

175. One category of cases in which private bargains may be unlikely to arise-and yet it may nonetheless be optimal to rely on-are the subcontractor bidding cases. In these cases, informational certainty renders it difficult for the parties to negotiate a fully binding contract before a reliance investment must be made. The subcontractor must make an offer, which the general will use to make its offer, and yet, the general contractor cannot make an unconditional acceptance to use the subcontractor because of the uncertainty over whether he will be awarded the overall contract. Recognition that uncertainty problems hinder conventional contracts, and to protect the general contractor's reliance on the subcontractor's offer, the law implies a term of irrevocability for the subcontractor's offer.

176. 582 So. $2 d 799$ (Fla. Dist. Ct. App. 1991).

177. Id. at 800 . The insurance company issued a certificate showing that employees of the subcontractor were covered. Id.

178. Id. at 801 . 
Coast is not directly involved in a contract with them. Thus, it would be relatively difficult for the subcontractor and Gulf Coast to negotiate a bargain that included the third party insurance company. Reliance on proof of coverage by a third party, not a party to the contract, would therefore seem to be a relatively efficient means of promoting reliance and minimizing the resources devoted to the insurance coverage issue.

Another factor in which promissory estoppel issues may arise in the context of a bargain involves the issue of contract interpretation. If the parties have reached a bargain, a question of how to interpret that contract may arise and promissory estoppel analysis may assist a court in that process of interpretation. In grappling with such issues, courts take into account welfare effects and efficiency concerns in interpreting contracts and applying promissory estoppel to existing contracts, although they do not do so explicitly.

If the mere fact that a completed bargain exists on the subject precluded any application of promissory estoppel, then these cases would be simple: the presence or absence of a bargain would automatically lead to a failure for a promissory estoppel claimant. The fact that courts still apply promissory estoppel in cases with an extant bargain shows that there may be another underlying concern: efficiency.

The presence of a contract, however, is not dispositive and a plaintiff may prevail under Section 90 even if a contract exists. ${ }^{179}$ In some cases the court may allow the promissory estoppel claim to proceed even without addressing the contract issue. In cases where the plaintiff prevails despite the existence of a possible contract claim and the court allows the promissory estoppel claim to proceed, it may be because the court is convinced that a liability default rule may be the most cost-effective way to promote efficient behavior by controlling opportunistic behavior by defendants (and would-be defendants). In cases where the court denies the promissory estoppel claim and justifies the denial of the claim in terms of the doctrine that promissory estoppel claims must fail where a bargain exists, the cited doctrinal reason may not really explain the outcome in the case. Instead, because courts do not invariably deny recovery whenever a contract exists, there must be another explanation that can account for the variegated outcomes. Efficiency appears to account for the different results. Where a promissory estoppel claimant tries to prevail in a case in which he would fail under the express contract, the court is reluctant to allow him, in effect, two bites of the apple or to act opportunistically to gain an advantage that he did not enjoy under contract. Allowing the promissory estoppel claimant to succeed in such circumstances would be inefficient because it would upset an agreed upon bargain allocation. But the existence of

179. See Royal Fixture Co. v. Phoenix Leasing, 891 S.W.2d 553, 554, 556 (Mo. Ct. App. 1995). 
a contract, whether unenforceable or not, does not preclude recovery when a grant of promissory estoppel recovery would actually promote efficient outcomes. Thus, where a contract exists, but the agreement is unenforceable, the court may allow a promissory estoppel plaintiff to prevail where a defendant has gained significant benefits from the plaintiff. If the law permitted the defendant to prevail against the promissory estoppel claimant while acting opportunistically, in future cases it would inefficiently discourage promisees from investing and providing the sunk costs sought by and beneficial to promisors. ${ }^{180}$

Doctor's Co. v. Insurance Corp. of America ${ }^{181}$ illustrates how efficiency concerns affect the availability of promissory estoppel when a contract exists. In Doctor's, a doctor helped to treat an emergency room patient who suffered serious injuries during the course of his treatment. The doctor had a "claims-made" insurance policy with defendant and was named in interrogatories, but was not actually made party to the suit until after he switched to a different insurance carrier. ${ }^{182}$ At the time the doctor switched, he disclosed that he had not yet been made party to the suit, but that he had been named in an interrogatory relating to the negligence suit. 183 When he was finally named in the lawsuit, neither insurance company would pay his claim. A declaratory judgment action was commenced by the second insurance carrier. 184 The court found that the doctor's second insurer was responsible for the claim and that the doctor should prevail against the second carrier on the basis of promissory estoppel, finding that the carrier "created detrimental reliance on the part of Dr. Peters when it issued a professional liability insurance policy without language expressly excluding coverage for the potential claim."185

This case illustrates the welfare effects a law-supplied default liability rule can provide; plaintiff was clearly in the best position to provide information to the doctor that would have made him change his position (i.e., stay with his previous insurer), but failed to do so. ${ }^{186}$ The insurer's denial turned on a "tortured" interpretation of

180. See Bravo v. Evans, No. 01-94-00696-CV 1995, Tex. App. LEXIS 999, at *1 (May 11, 1995) (holding earnest money agreement not enforceable where promissory estoppel claimants had paid for repairs, homeowners assessment fees and twelve equity payments toward purchase of house, and since defendants had benefited significantly from such payments, plaintiffs could recover on promissory estoppel claim where earnest money contract admittedly unenforceable).

181. 864 P.2d 1018 (Wyo. 1993).

182. Id. at 1022 .

183. Id.

184. Id.

185. Id. at 1029 .

186. In his disclosure, the doctor informed insurer of the pending action, but said, "I was not sued." Id. at 1022 (emphasis deleted). 
the words "claim" and "first made."187 The appeals court and trial court rejected plaintiff's readings of their unambiguous contract, and found it unjust to deny coverage to the doctor. 188 Plaintiff was in the most efficient position to assess information at the onset of coverage; it could have, at little cost, appraised the potential liability the suit could expose it to, and then adjusted premiums to compensate, or crafted an explicit liability cap. Not enforcing the policy and allowing the contract exclusion to be literally interpreted would foster distrust and more uncertainty, and would significantly raise the cost of insurance renegotiation.

\section{Weak Cases}

If one assumes that contract rules, including promissory estoppel, should be applied in such a way as to maximize the welfare effects of the rules, then it becomes possible to understand some of the recent negative results in promissory estoppel claims. Courts have ruled against promissory estoppel claimants when the promise was ambiguous, the reliance preceded the promise, ${ }^{189}$ the document contained a clear disclaimer, ${ }^{190}$ the promise was not actually broken, ${ }^{191}$ the plaintiff actually suffered no loss, ${ }^{192}$ the prior promise was contrary to a subsequent written contract, ${ }^{193}$ the promisor revoked the promise before the reliance occurred, ${ }^{194}$ there was no detrimental reliance, ${ }^{195}$ or the promises were too vague to warrant the application of promissory estoppel. ${ }^{196}$ Although these particular categories of

187. Id. at 1025 .

188. It would have been more efficient to plaintiff to have initially refused to cover the doctor, or to craft a liability clause explicitly disclaiming that it would not be responsible for the suit. Both of these actions would have come at a very low cost to plaintiff, but failing to make them at the time coverage was initially granted produced very high costs (litigation, for example).

189. McKenny v. John Carr \& Son, 922 F. Supp. 967, 980 (D. Vt. 1996) (claiming that "[t]he theory of detrimental reliance applies when the promise comes first and induces the subsequent action in reliance").

190. See supra note 90.

191. See supra note 88.

192. Belanger v. Boise Cascade Corp., 968 F.2d 254, 257, 259 (2d Cir. 1992).

193. George Hammersmith, Inc. v. Taco Bell Corp., No. 90-35460, 1991 U.S. App. LEXIS 19716, at *20 (9th Cir. Aug. 15, 1991); Kinn v. Coast Catamaran Corp., 582 F. Supp. 682, 687 (D. Wis. 1984).

194. Clancey v. G.F. Wright Steel \& Wire Co., No. 95-0239, 1998 Mass. Super. LEXIS 150, at*10 (April 1, 1998).

195. Collins v. Old Republic Title Co., No. 97-3255, 1998 U.S. App. LEXIS 31807, at *6 (10th Cir. Dec. 23, 1998); Chrisman v. Philips Indus., Inc., 751 P.2d 140, 146 (Kan. 1988).

196. Peterson v. Beebe Med. Ctr., No. 91C-07-147, 1992 Del. Super. LEXIS 454 , at ${ }^{*} 12$ (Nov. 13, 1992). For obvious reasons, the courts are skeptical of finding an implied contract when the existence of one is not objectively certain. In Seattle-First National Bank v. Westwood Lumber, Inc., 829 P.2d 1152, 1154 (Wash. Ct. App. 1991), an appellate court reversed a finding of promissory estoppel because there was no definite promise, and it could be inferred that there was notice that a promise was not yet finalized (the plaintiffs "realized that no 
failure are all separate, they can best be understood in welfare effect terms. Were courts to employ a liability rule in the precontractual phase of bargaining when such factors are present, they would be intervening where intervention would be unnecessary or counterproductive.

Orback v. Hewlett-Packard Co. ${ }^{197}$ illustrates a convergence of several of these factors and typifies a weak claim.198 In Orback, a group of employees sued on wrongful discharge. The employees attempted to construct a promissory estoppel claim on the basis of a termination procedure contained in the personnel manual. In $\mathrm{Or}$ back, the manual was not actually distributed to employees at all but only to managers, and the termination procedure itself provided the managers with discretion in how to apply the termination procedures. In addition to the foregoing, the manual contained a disclaimer. 199 Many of the employees who sued had neither received a copy of the manual nor actually read the provisions on termination, though at least one employee "became aware of it through rumors from other employees." 200 Moreover, the court found that there was no evidence that the termination procedures had actually been breached. ${ }^{201}$

increase in their line of credit would be effective until approved by [defendant's] superiors"). A similar set of facts exists in Bridges v. Reliance Trust, 422 S.E.2d 277 (Ga. App. 1992). Once again, an obviously indefinite promise from a bank was insubstantial to support a promissory estoppel claim.

197. 97 F.3d 429 (10th Cir. 1996).

198. Other weak claims include: Burrell v. Carraway Methodist Hosps. of Ala., Inc., 607 So. 2d 193, 196 \& n.3 (Ala. 1992) (no promissory estoppel action for wrongful employee discharge when employee handbook clearly stated that employee could be discharged "with or without cause" and only favorable evidence was "general behavior of the hospital"); Chellsen v. Pena, 857 P.2d 472 (Colo. Ct. App. 1992) (Where city charter clearly stated probationary employees could be terminated at will, no limitations on termination would be implied under promissory estoppel.); Trifelos v. Gen. Tire, Inc., No. CA-8993, 1992 Ohio App. LEXIS 6661 (Dec. 21, 1992) (Company's nebulous statements that it would consider laid off plaintiff for future job openings precluded reasonable reliance.); Washington v. Cleveland Clinic Found., No. 61556, 1992 Ohio App. LEXIS 6249 (Dec. 10, 1992) (Where employee is arrested on charges of drug trafficking, her promissory estoppel claim fails where she argues that a promise to review employment status actually constitutes a promise for continued employment.); Healey v. Republic Powdered Metals, Inc., 619 N.E.2d 1035 (Ohio Ct. App. 1992) (company president's statement on plaintiff's 37th anniversary year that plaintiff would be company's first 50-year employee not a binding promise, precluding reasonable reliance); Bisbee v. Grogan Chrysler-Plymouth, Inc., No. L 91-323, 1992 Ohio App. LEXIS 3599 (July 10, 1992) (Where court's review of record revealed "no evidence of any specific promise of job security" promissory estoppel cannot be invoked as an exception to the at-will employment status of employee.).

199. Orback, 97 F.3d at 433.

200. Id. at 432 .

201. Id. at 433 . 
Orback seems like a particularly weak case for many reasons. Finding liability in such a case would seem likely to promote inefficient behavior by promisor/employers. In cases where employers disclaim the existence of a contract or fail to distribute the manual to employees, the employees fail to read any of the relevant provisions, or the employer actually complies with the promised termination procedures, it would seem inefficient for a court to impose liability using promissory estoppel theory. The employer had actually limited the distribution of the personnel manual so that employees did not receive copies of the manual. To allow employees to claim reliance successfully in such a weak case would impose large costs on potential promisors. They would have to take extraordinary steps to ensure that employees did not rely on policy manuals even if the manuals were not intended for them, even if the policy actually gave the employer discretion as to the termination procedure so that a mandatory termination procedure was not required and even when the evidence showed that the promises were actually followed and not broken. Because reliance by employees would seem to be unreasonable, imposing liability in such cases would entail large reversal costs by employers who would have to adopt even greater precautionary assurances to ensure that the employees did not rely. Such a result would seem to be an inefficient use of resources, and thus, denying liability would seem to maximize gains from trade. If this explanation for what courts are doing in promissory estoppel cases makes sense, then it becomes readily apparent why plaintiffs are losing in many current cases. The fact patterns simply do not present the potential for the opportunistic exploitation of sunk costs in a way that demands court intervention in the form of a liability rule.

Venable $v$. Venable 202 is another weak case in which promissory estoppel was invoked by a plaintiff where evidence of the reliance is questionable and in which the imposition of a law-supplied rule to foster efficient reliance by promisees seems unnecessary. In Venable, the plaintiff and defendant were getting divorced and they owned a house upon which they owed money at the time of divorce. Plaintiff told the defendant that he would not pay any more money on the debt unless she gave him a quitclaim on the property. ${ }^{203} \mathrm{Al}$ though the plaintiff-husband paid toward the debt, the wife refused to execute a quitclaim deed. As a result, the property was divided as marital property. The plaintiff brought an action in promissory estoppel to enforce the promised quitclaim. The court denied promissory estoppel. It found no reliance since the plaintiff was required to pay toward the debt regardless of whether the defendant made a promise or not. ${ }^{204}$

202. No. CA 91-252, 1992 Ark. App. LEXIS 253 (Mar. 25, 1992).

203. Id. at *3.

204. Id. at *4. 
In this case, the reliance that is claimed, payment on an existing debt, has in a sense already preceded the promise because the sunk cost — the debt—was incurred prior to the defendant's promise to deliver the quitclaim deed. To make the defendant liable for a reliance that has already occurred would make a promisor liable for actions over which she has no control and presumably would increase the costs of contracting as parties took precautionary measures to avoid being held responsible for reliance which precedes the promise.

The result in the case (a negative finding of promissory estoppel) makes sense if one focuses on the justification for promissory estoppel as a law-supplied liability rule designed to promote optimal reliance. Courts grant promissory estoppel claims when they are convinced that the rule is needed to promote optimal reliance. In cases where a promisor solicits sunk costs from a promisee to reduce uncertainty for the promisor, there is a danger of opportunism, which will decrease joint gains from trade. It makes sense for the law to supply such a rule where it is convinced that doing so is less costly than private devices parties would use in its absence. In cases like Venable, where the major sunk cost has occurred before the promise, it would not seem necessary for the law to protect such investment. When reliance investments are made prior to the promise, the law's intervention with a liability rule would not make sense as some investments have been and will continue to be made independently.

\section{CONCLUSIONS}

In 1997, Professors Robert Hillman and Sidney DeLong challenged the view of the vast majority of American Contracts scholars by proclaiming promissory estoppel to be an unimportant doctrine. In so doing they rejected the dominant view of promissory estoppel found in Grant Gilmore's 1974 book, The Death of Contract. That view posited that promissory estoppel had swallowed up bargain theory and reoriented contract law to a new tort-like theory of liability. This Article suggests that the 1997 counterrevolution must fail because the empirical conclusions are based on an analysis of win rates that do not control for various characteristics of the contracts opinions. Once those factors are accounted for in the data, the claims of promissory estoppel's demise cannot stand. This Article draws several conclusions. First, an examination of the empirical data shows that it may be difficult to draw meaningful conclusions from a generalized win/loss rate. Such losses might indicate very little about whether a plaintiff with a viable claim will succeed or fail. A large number of losses may indicate nothing more than that in a non-random series of cases, where there are a large number of non-viable claims, the plaintiff is likely to lose. Losses in such cases may have little to say about the general receptivity to a promissory 
estoppel claim when the facts are strong or the plaintiff has not committed a serious error. The Article concludes that when relevant factors of contracts opinions are accounted for in the data and the win/loss rates, promissory estoppel is, in fact, an important theory in the law of contracts. Thus, to determine the importance of the theory, one must first analyze the cases to determine whether the claims are demonstrably weak claims or viable ones. I used a variety of factors to make that determination. ${ }^{205}$ When demonstrably weak claims are subtracted from the data set, promissory estoppel claims succeed at a rate that is not dissimilar from that of the percentage of cases winning across a broad range of categories involving all types of claims. ${ }^{206}$ Promissory estoppel claims are likely to prevail when the case is, in fact, a colorable claim. On the other hand, the case is more likely to fail when the facts are indicative of a weak claim. ${ }^{207}$

This reinforces a conclusion of empirical scholars that a particular data set is often difficult to interpret. As Ted Eisenberg explains, "win rates' are probably the slipperiest of all judicial data."208 The lack of success could be due to many factors, including the non-random way in which cases are selected for trial. 209 Unless one has a particular hypothesis to prove, it may be difficult to assert that any result is a win or loss unless it is tied in some particular way to the hypothesis.

Finally, some of the conclusions that can be drawn from the data (and from Hillman's own data) suggest that in some ways the

205. See supra note 91.

206. Measuring success rates is an extremely complicated enterprise for many reasons. Hillman has chosen to compare promissory estoppel win rates, calculated exclusively by wins on the merits, to win rates enjoyed by contracts cases compiled by the Federal Judicial Center. Success rate data exist for both contract claims as well as a mixture of all civil type claims in the compilation/data set compiled by the Federal Judicial Center. The Federal Judicial Center collects the data, and the Inter-University Consortium for Political and Social Research publicizes the data. This data is now readily available through a Cornell University Web site: http://teddy.law.cornell.edu:8090/questcv2.htm.

I have chosen to compare the "success" rate of promissory estoppel claims to the overall success rates of a mixture of claims, rather than simply contract claims, for a variety of reasons. Simply stated, the contract claims that form the base for tracking the success rate of contract claims in the Federal Judicial Center database of cases do not seem representative of typical contracts claims. Several of the categories would have predictably low success rates and so would drive the win rate down for all contract claims.

207. I identified a number of factors indicative of a weak claim. These include situations in which the promisee's reliance preceded the promise, the promise was not broken, or in which the promissory estoppel claimant was guilty of bad conduct or bad faith in bringing the claim. Cases are also weak for reasons having nothing to do with the merits of the promissory estoppel claim, such as procedural errors or preemption.

208. Clermont \& Eisenberg, supra note 101, at 581.

209. Priest \& Klein, supra note 67. 
courts are still struggling with the question that has troubled scholars from the beginning: what role does/should promissory estoppel play in the landscape of contract law? There has been a lack of consensus in the scholarly literature on this difficult issue of how reliance and bargain theory should fit together in one theory of promissory liability.

Although it has been difficult to reconcile these theories, it is my contention that if these factors and others are examined in detail, they offer some important picture of the place that promissory estoppel is assuming in contract law. Promissory estoppel wins and losses demonstrate that when courts are grappling with whether to imply a liability rule making a promisor liable for pre-contractual losses, a key underlying concern is with whether intervention in such cases would promote efficiency. 


\section{APPENDIX}

\section{Formulas Used on Summary Sheet}

1) Succ./Total represents the percentage of wins out of all cases examined. This number is not very useful as it includes even those cases where $\mathrm{P} / \mathrm{E}$ was not found in the case.

$\underline{\text { P/E Successful }}$

\section{Succ. $/$ Total $=$ Total Cases}

2) Succ./Total - Moot and irrel. represents the percentage of claims accepting $\mathrm{P} / \mathrm{E}$ when the claim is addressed and decided.

\section{$\underline{\text { P/E Successful }}$}

Succ. $/$ Total - Moot and irrel. $=$ P/E Successful + P/E Not Successful + No P/E, But

3) Succ./Not succ. + Succ. represents the percentage of cases accepting $\mathrm{P} / \mathrm{E}$ when the case is decided on the $\mathrm{P} / \mathrm{E}$ claim.

\section{$\underline{\mathrm{P} / \mathrm{E} \text { Successful }}$}

Succ./Not succ. + Succ. $=$ P/E Successful + P/E Not Successful

4) Succ. + No, but/Total - Moot and irrel. represents the percentage of winning plaintiffs in cases where $\mathrm{P} / \mathrm{E}$ was a relevant claim.

$\underline{\text { P/E Successful + No P/E, But }}$

Succ. + No, but/Total - Moot and irrel. $=$ P/E Successful + P/E Not Successful + No P/E, But

5) Succ./Not Succ. gives the ratio of the number of cases where the $\mathrm{P} / \mathrm{E}$ claim was successful to the number of cases in which all claims, including $\mathrm{P} / \mathrm{E}$ were unsuccessful.

$\underline{\text { P/E Successful }}$

Succ./Not Succ. $=$ P/E Not Successful 
6) Succ. + No, but/Not Succ. gives the ratio of the number cases in which the $\mathrm{P} / \mathrm{E}$ claimant won on some cause of action to the number of cases in which the $\mathrm{P} / \mathrm{E}$ claimant lost.

P/E Successful + No P/E, But

Succ. + No, but $/$ Not Succ. $=$ P/E Not Successful 